\title{
DISASTERS AND CRISIS MANAGEMENT -AN ADVANCED APPROACH TO DEAL WITH CRISIS
}

\section{Khaled M. A. El-Lithy}

Assistant Professor, Architecture Department, Faculty of Engineering Assiut University, Assiut, Egypt

(Received April 15, 2008 Accepted July 2, 2008)

This paper demonstrates the importance of disasters and crisis management as one of the main acts for disasters protection and prevention activities. As known, disasters and crisis are results of human behavior and actions against the dangers they are dealing with.

This paper focuses on studying the correlation between disasters and human behavior during the disasters management activities. This paper provides a methodology for disasters and crisis management components and stages of advanced information systems and management approaches to support the decision-making process during the stage of recovering the disasters such as floods, earthquakes and similar crisis.

The aim of this paper is to decrease of the quantity of damages and losses which may to thousands of houses and communities locate near to the disasters areas.

The paper provides an overall framework consisting from several useful points and guidelines in dealing with disasters and crisis.

The paper outlines some insights and recommendations which are expected to facilitate and optimize the utilization of scientific and technological and human resources available in regional and local government agencies and the information and decision making Support Centers.

KEY WORDS:Disasters and crisis management, Natural dangers, Behaviors and actions, human societies, Protection planning, Sustainable development

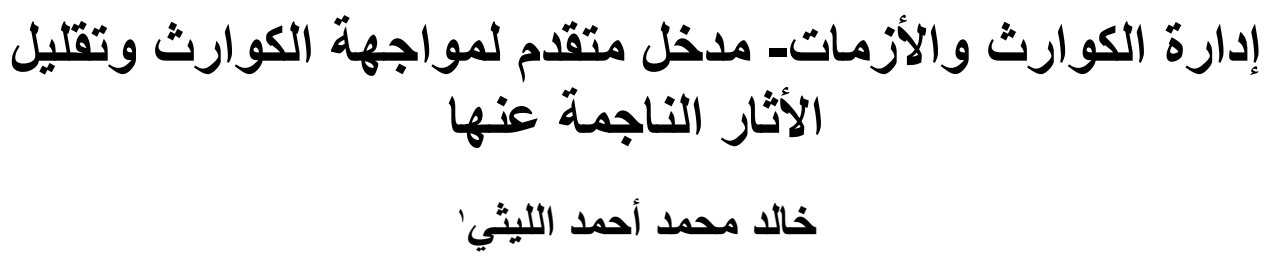

الملخص: تنـاقش الورقـة البحثيـة أهميـة إدارة الكوارث والأزمـات كأحد المهام الرئيسية

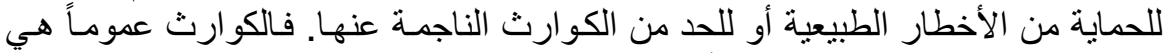

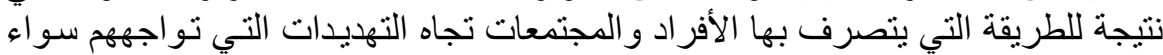

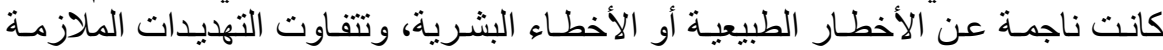

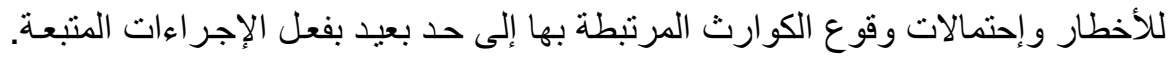

$$
\text { ' مدرس بقم الهندسة المعمارية ـ كلية الهندسة - جامعة أسيوط - أسيوط - جمهورية مصر العربية }
$$




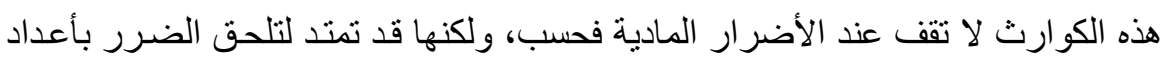

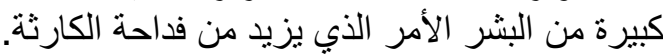

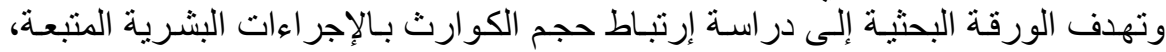

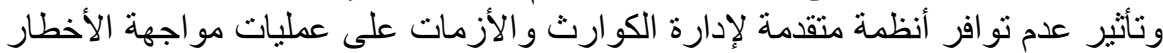

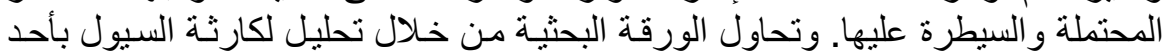

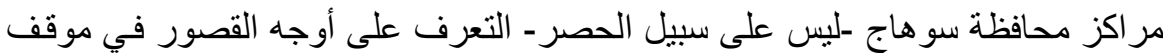

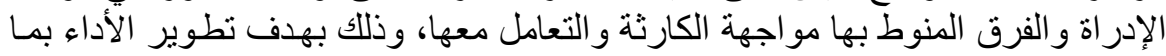
يكفل توفير بيئة آمنة للتجمعات البشرئة البشرية.

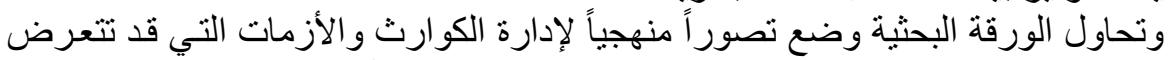

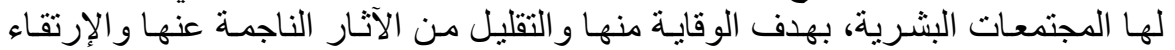

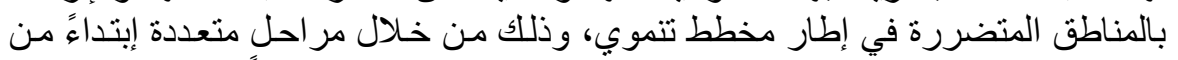

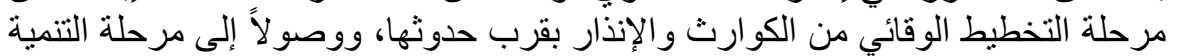
فيما بعد الكارثة.

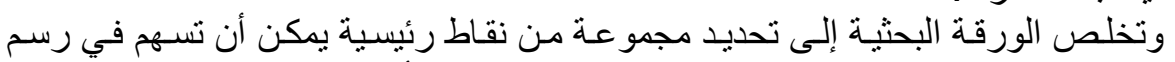

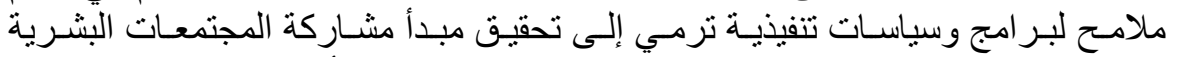

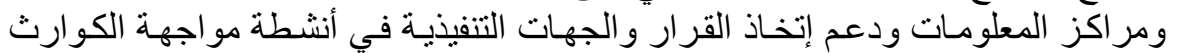

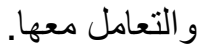

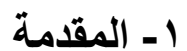

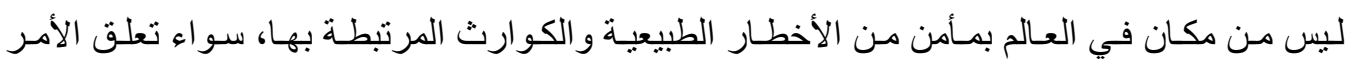

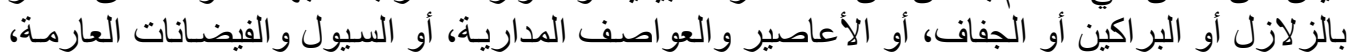

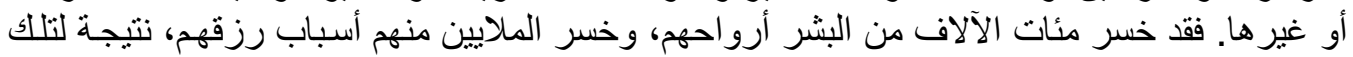

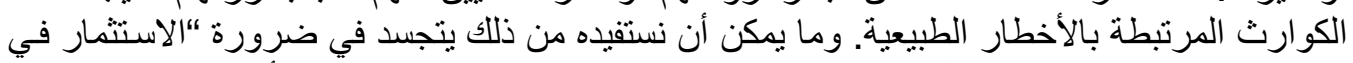

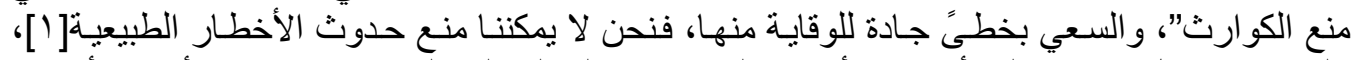

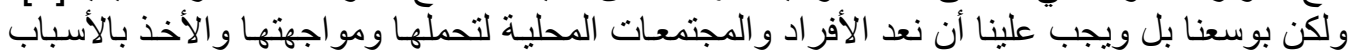

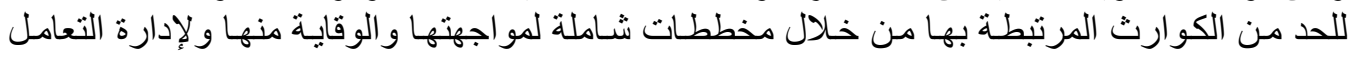

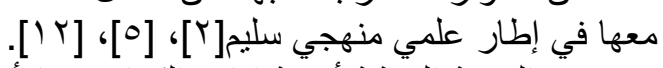

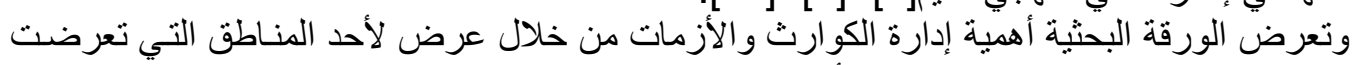

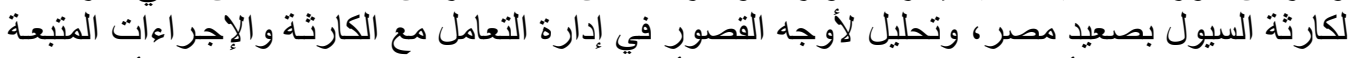

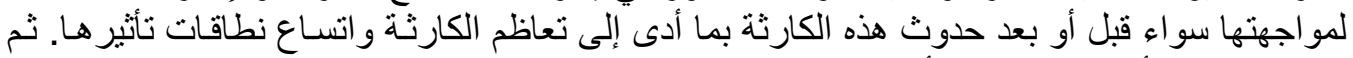

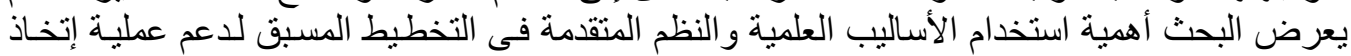

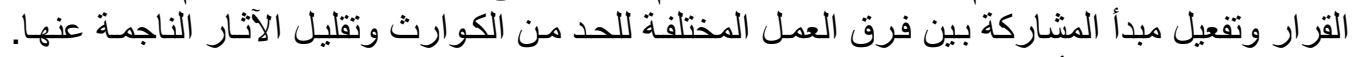

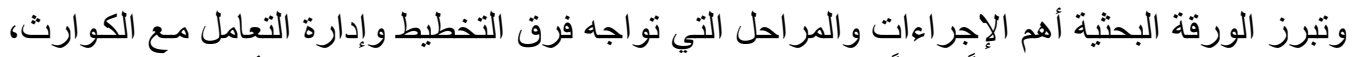

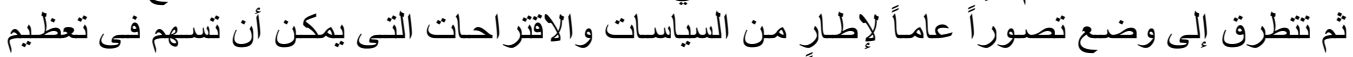

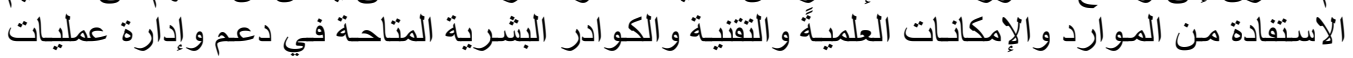

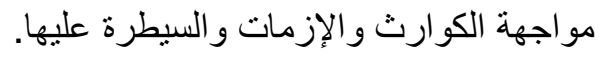

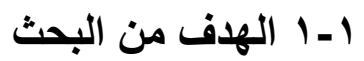

تهدف هذه الورقـة البحثية إلى الإستفادة من موقف الإدارة بعينـة الدراسـة في مواجهة كارثنة السيول

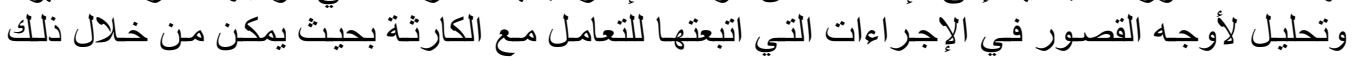

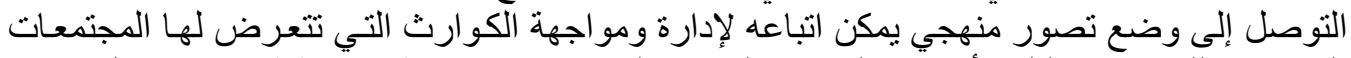

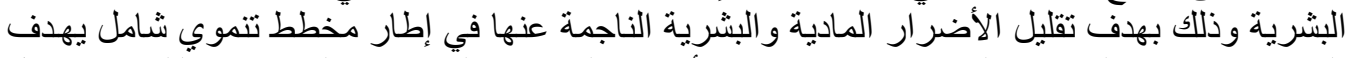

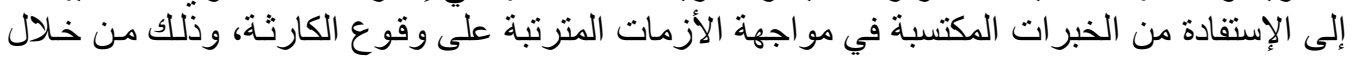




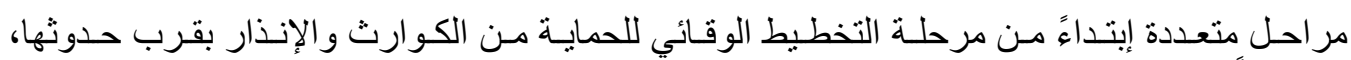

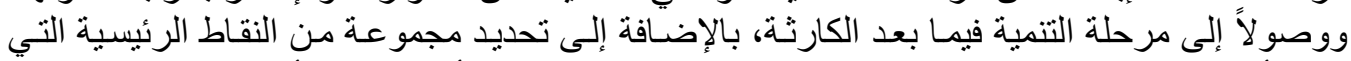

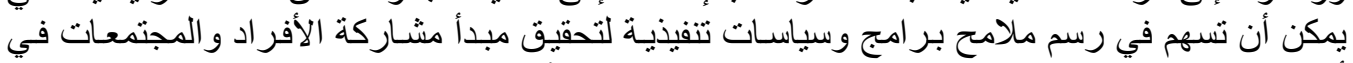
أنشطة مو اجهة الكوارث في و الوقاية منها بشكل يكفل توفير بيئة آمنة.

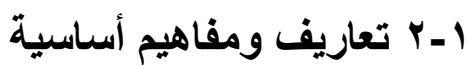

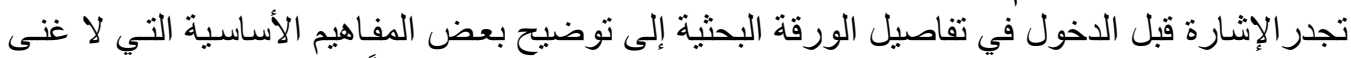

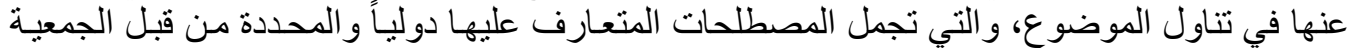

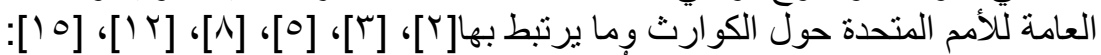

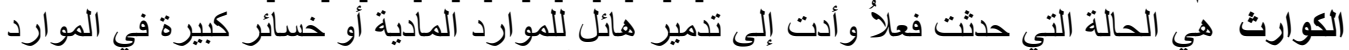

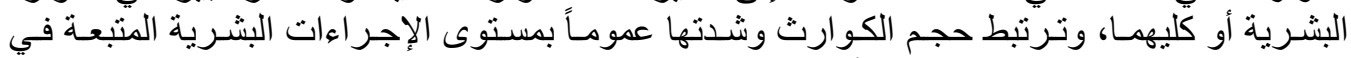

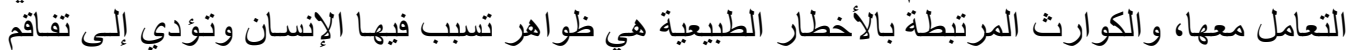

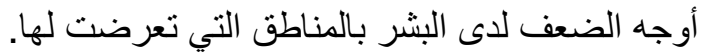

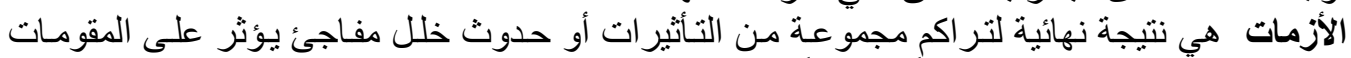

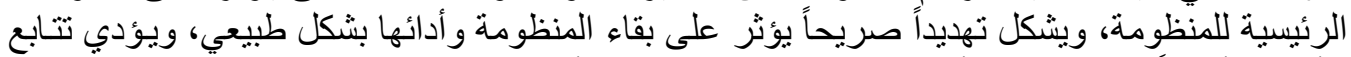

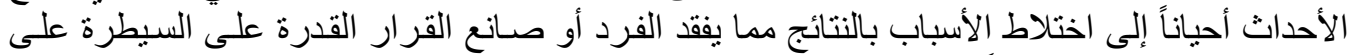

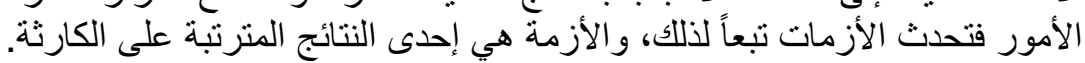

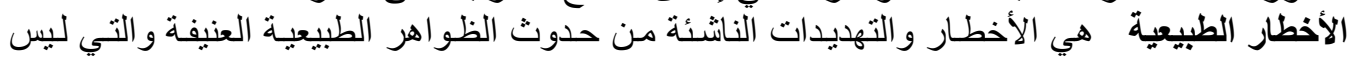

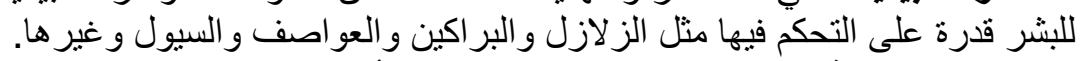

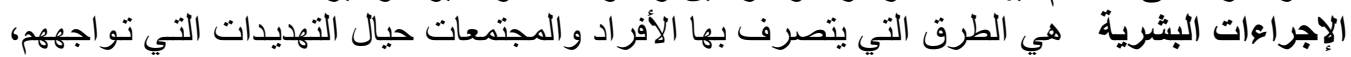

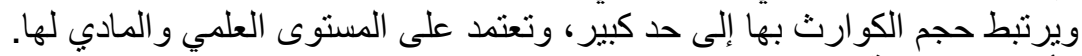

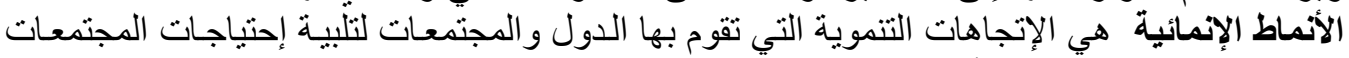

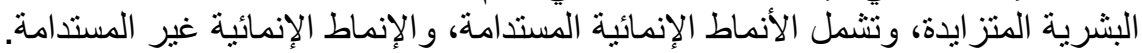

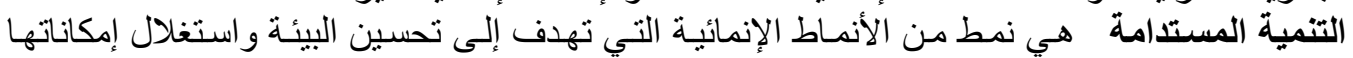

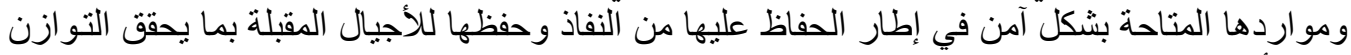

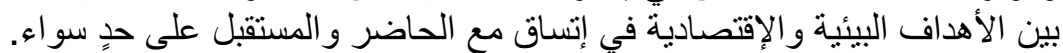

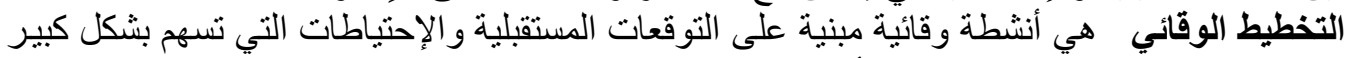

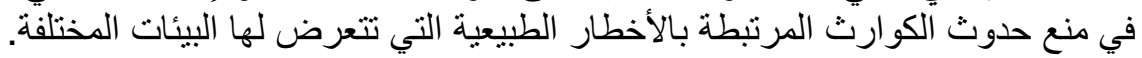

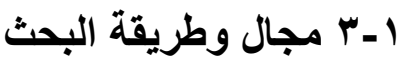

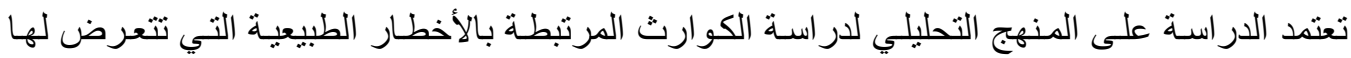

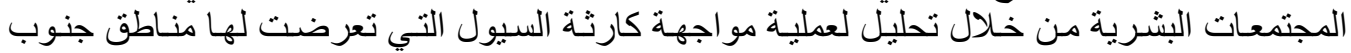

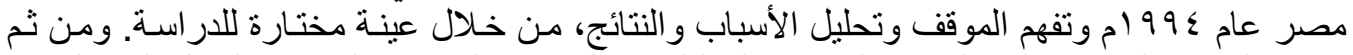

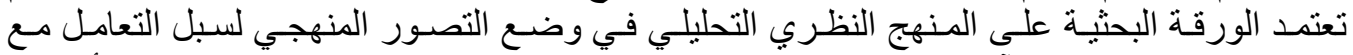

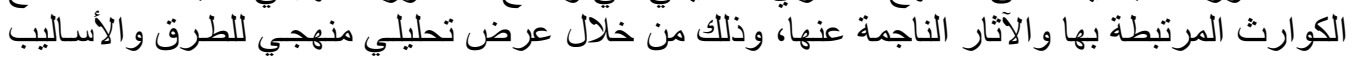

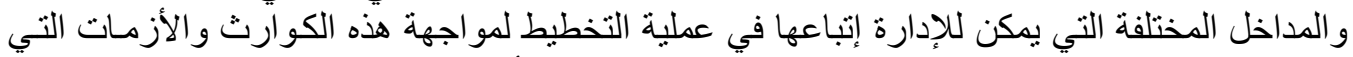

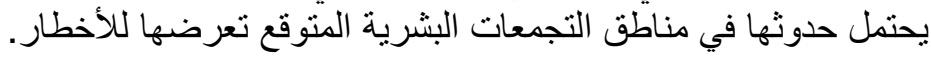

1 ـ أب البيانات والمعلومات

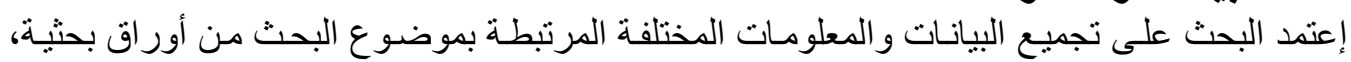

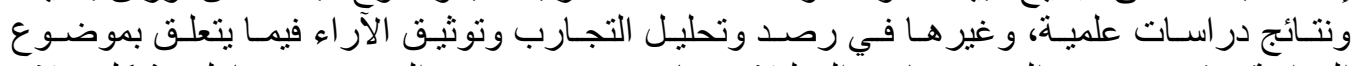

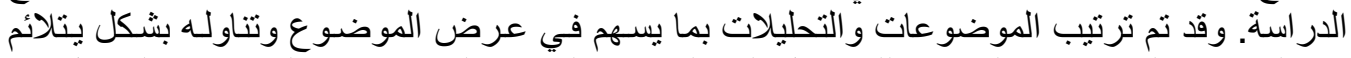

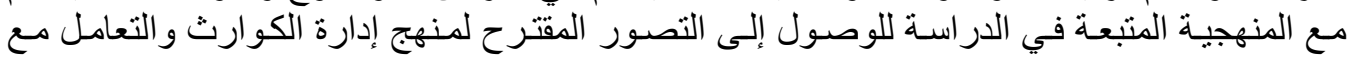


الأزمات المرتبطة بها، والذي يهدف إلى رسم ملامح المخططات و البرامج و السياسـات التنفيذية التي

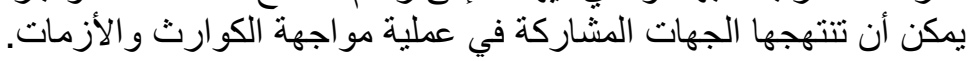

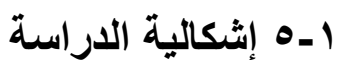

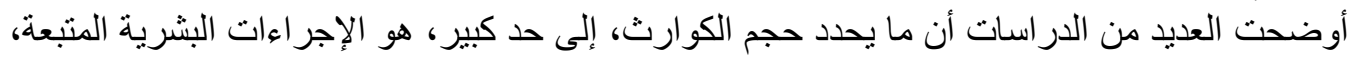

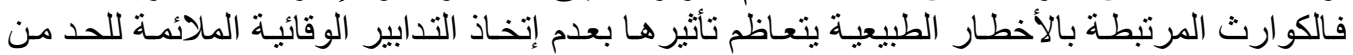

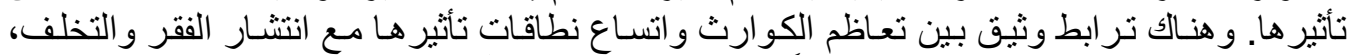

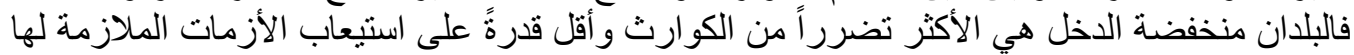

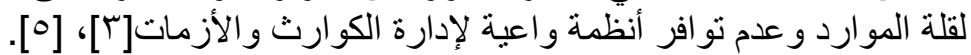

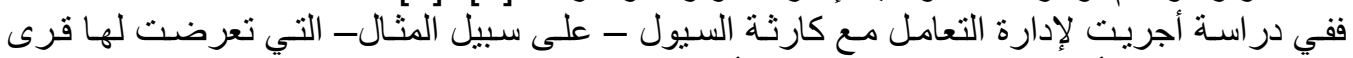

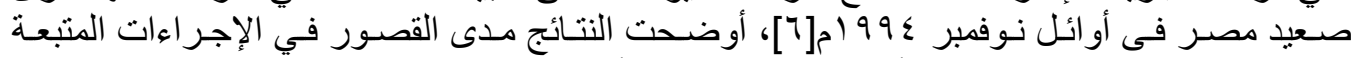

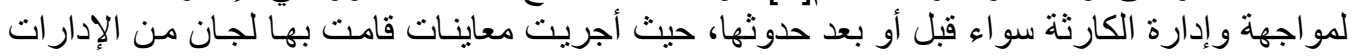

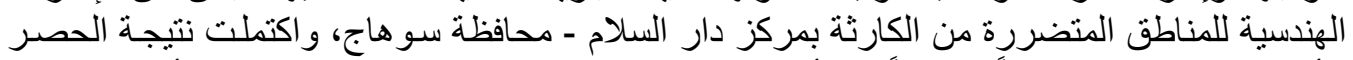

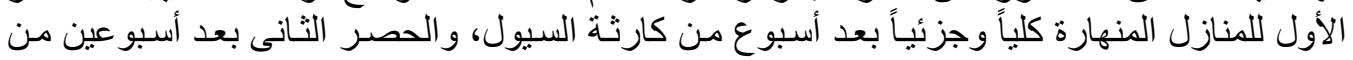

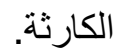

جدول (1) نتائج حصر الأضرار الناجمة عن كارثة السيول بمركز دار السلام بمحافظة سوهاج[?]

\begin{tabular}{|c|c|c|c|c|c|}
\hline المتضررين & الإنهيار الجزئى & الإنهيار الكلى & نوع الحصر & نوع الكارثة & منطقة الكارثة \\
\hline$\varepsilon \ldots$ & 90. & rio. & الحصر الأول & السيول & 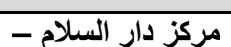 \\
\hline ro17 & $\leqslant 79$ & $T \cdot \sum V$ & الحصر الثانى & & محافظة سوهاج \\
\hline rroo & אדי & אוTאו & حصر اللجنة الإستشار & & \\
\hline
\end{tabular}

ومن فحص النتائج تبين أن بيانات الحصر الثاني جاءت أقل عدداً من بيانات الحصر الأول نظر اً لتشديد

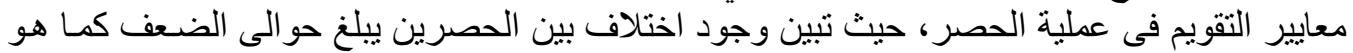

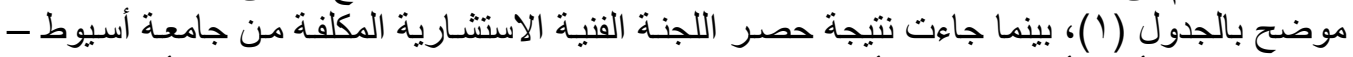

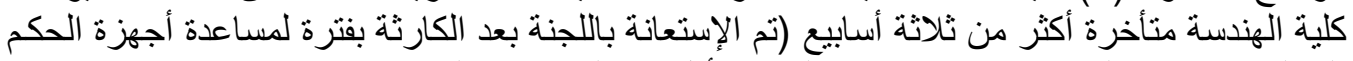

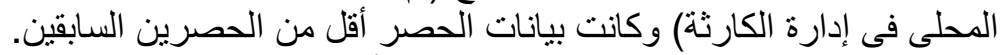

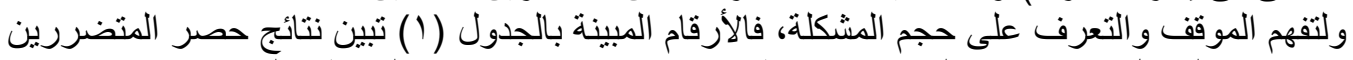

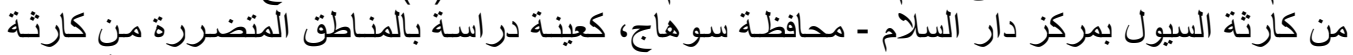

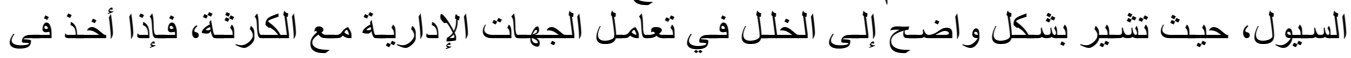

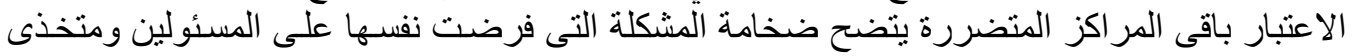

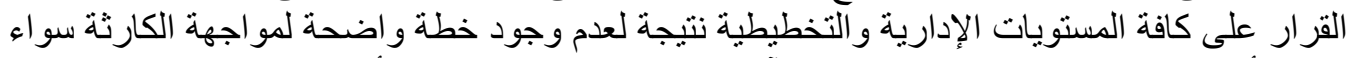

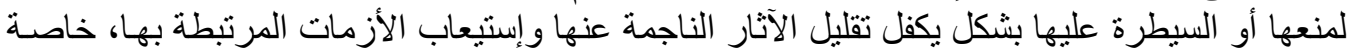

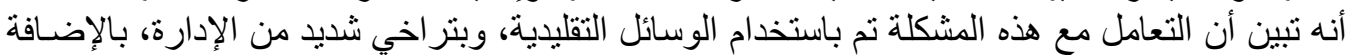

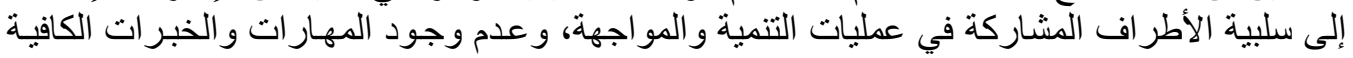

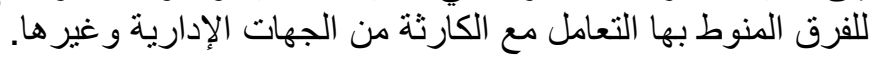




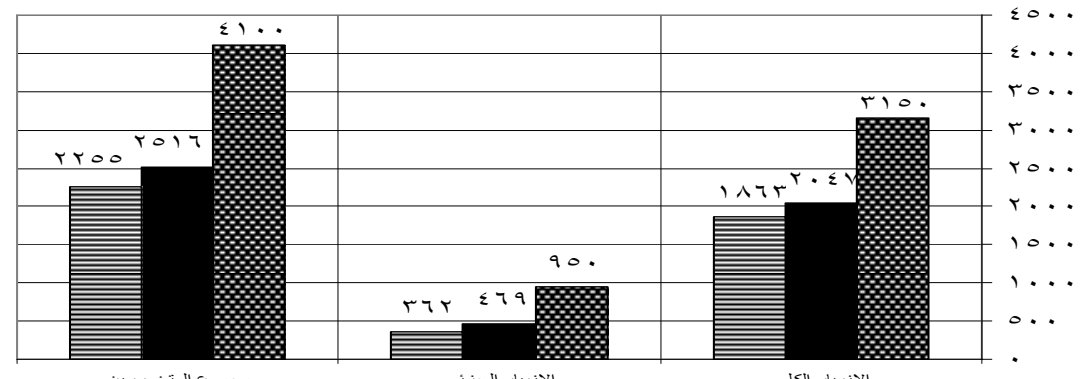

مجموع المتضسررين

ه الحصر الاون الخرون
الإنهيار الجزنى الجن

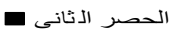

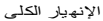

قصر اللجنة الإستشـارية الإلة

شكل (1) تضارب بيان اللجان المختصة لنتائج حصر الأضرار الناجمة عن كارثة السيول [ـ 1]

وبتحليل الموقف و الإجر اءات التي اتبعت في التعامل مع كارثة السيول وتفقد المو اقع المتضررة وتقدير

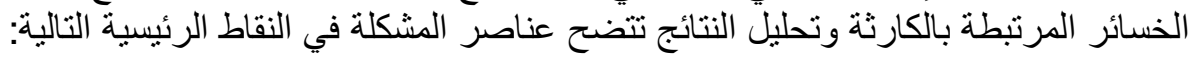

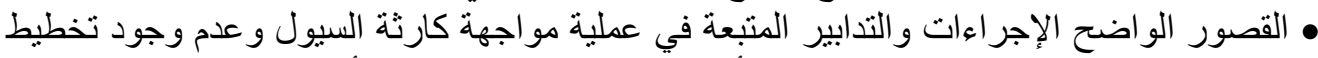

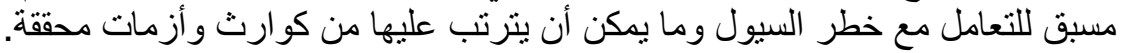

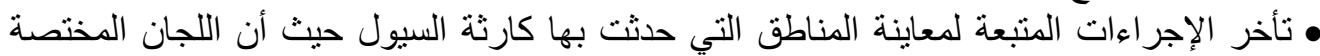

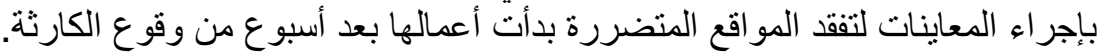

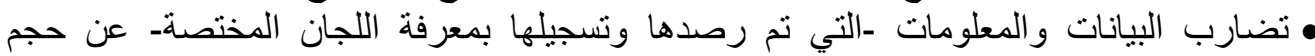

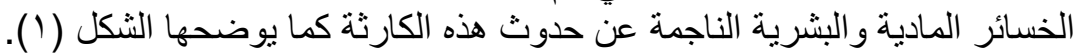

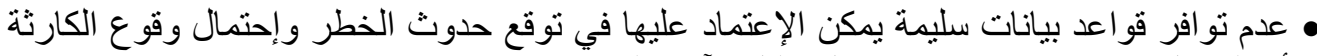
أو التعامل معها بعد حدوثها بما يكفل تقليل الآثار الناجمة الإنة عنها. • عدم توافر الكوادر والخبرات الفنية الكافية لاى الفران الفرق المنوط بها التعامل مع مثل هذه الكوارث و التخطيط لمواجهتها بشكل آمن. التران. • عدم دراية الجهات الإدارية وأجهزة الحكم المحلي بوسائل التعامل مع كارثة السيول والأزمات

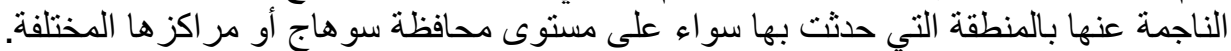

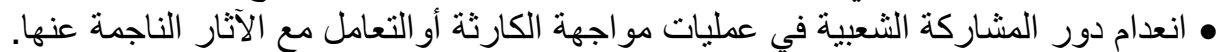

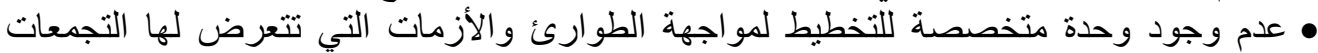
البشرية بالمدن و القرى بالمحافظات الفقيرة.

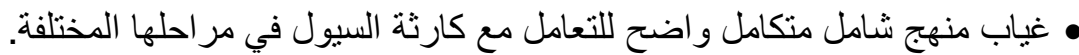

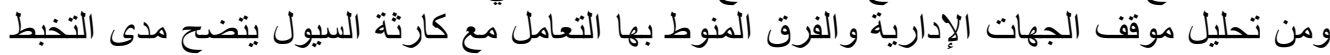

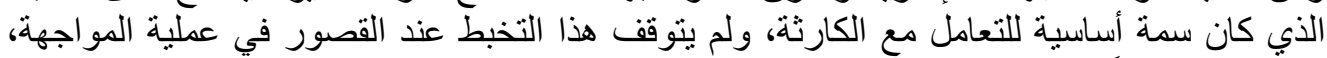

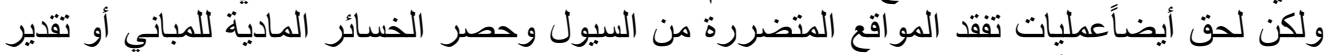

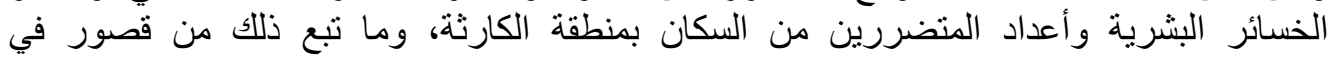
الإجر اءات المتبعة لعلاج الموقف وتتمية المناطق المتضررة فيما بعد حدوث الكارثة الكارثة.

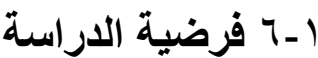

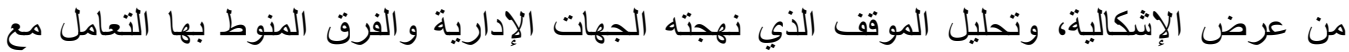

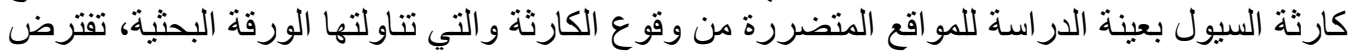

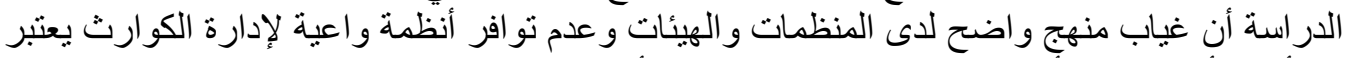

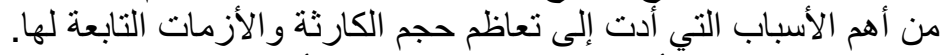

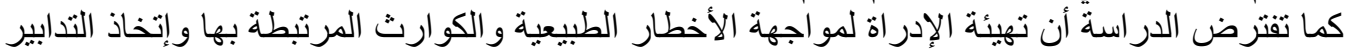

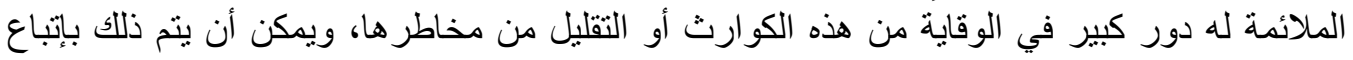




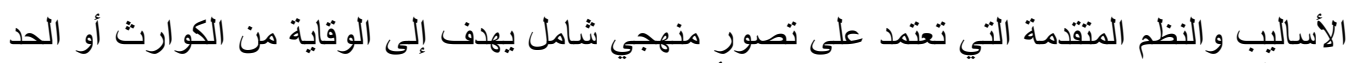

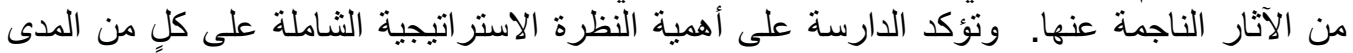

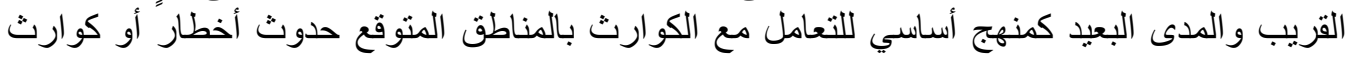

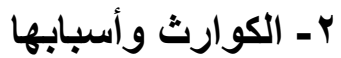

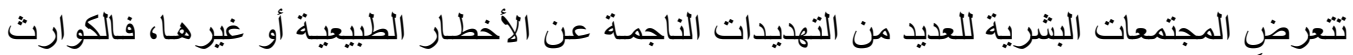

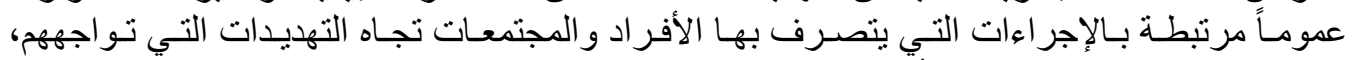

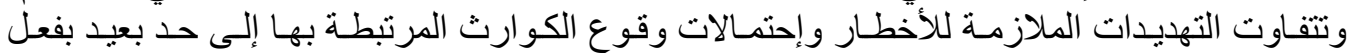

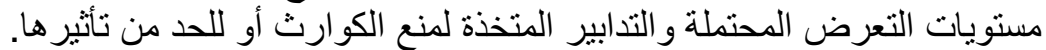

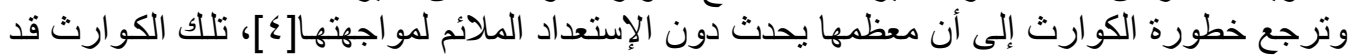

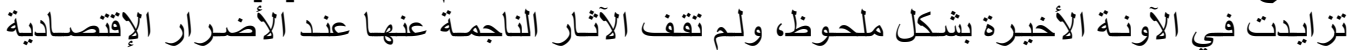

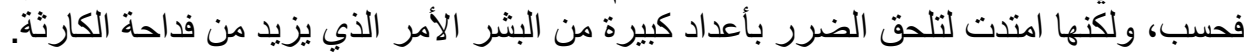

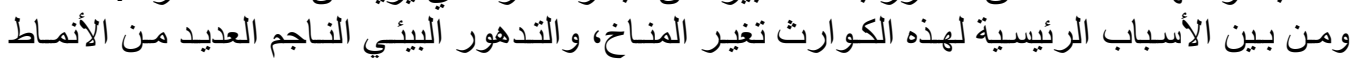

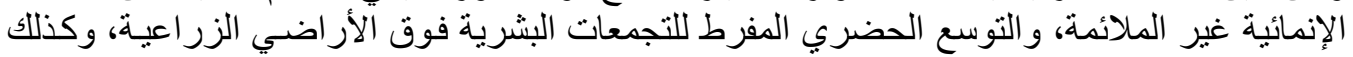

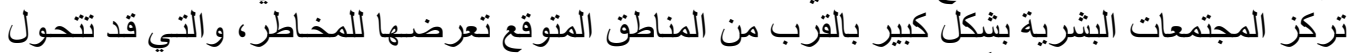

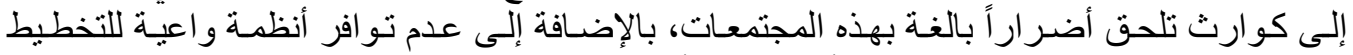

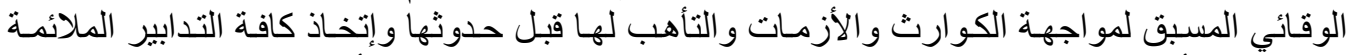

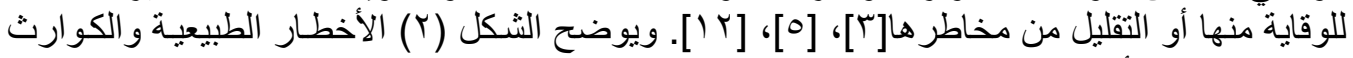
المرتبطة بها والأزمات الناجمة عنها.
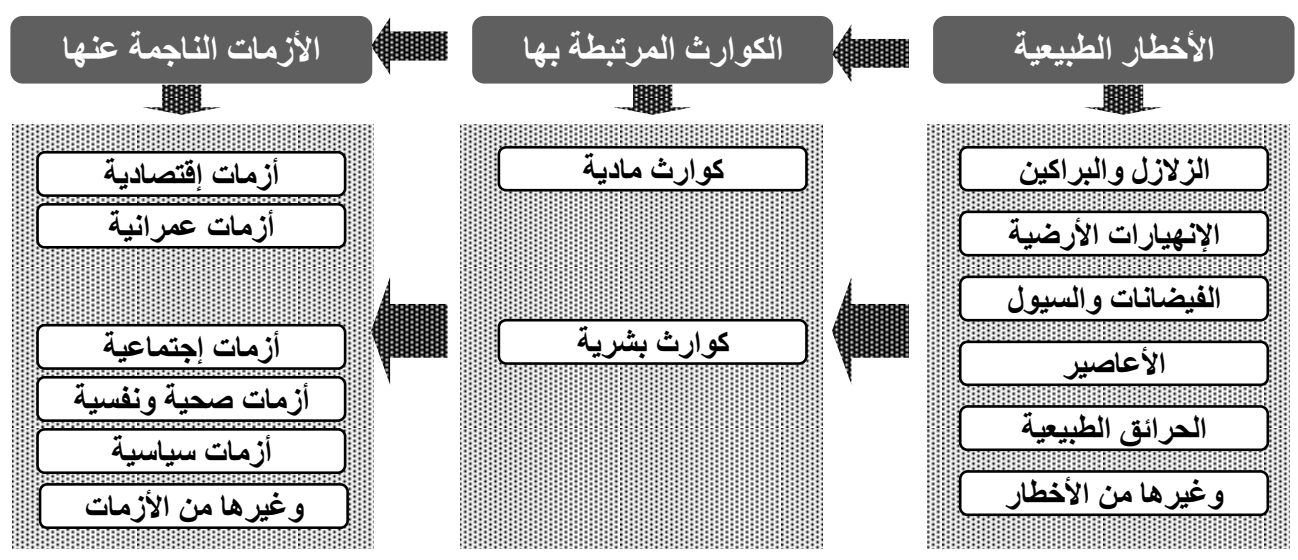

\section{شكل (Y) الأخطار الطبيعية والكوارث المرتبطة بها والأزمات الناجمة عنها]ـ إ]}

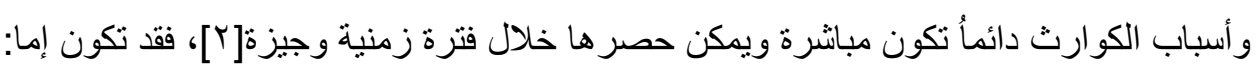

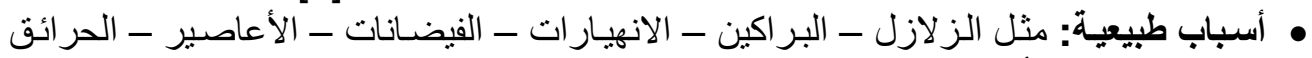

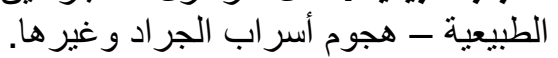

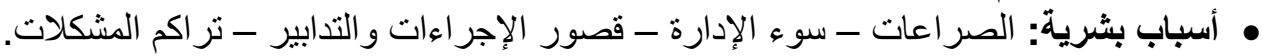

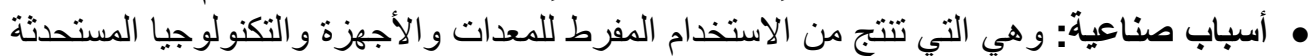
و الأنماط التنموية غير المستدامة وغير ها بشكل غير آمن. 
و الكوارث كما أن لها آثار ها السلبية إلا أن لها بعض العوامل الإيجابية في تعبئة المشـاعر القوميـة تجـاه

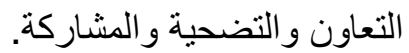

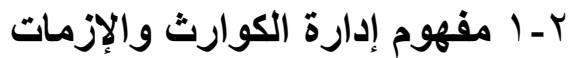

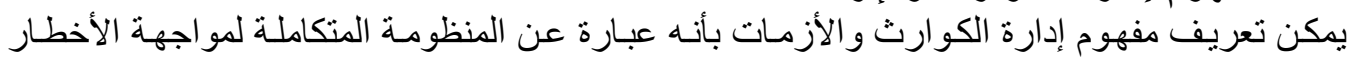

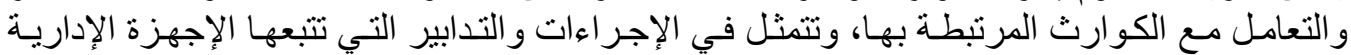

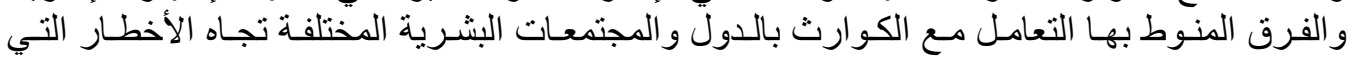

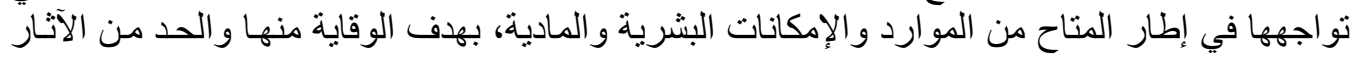

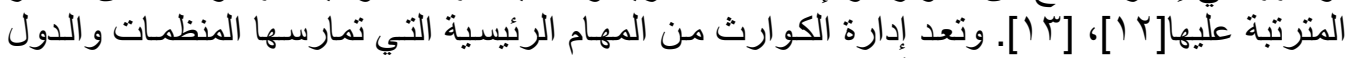

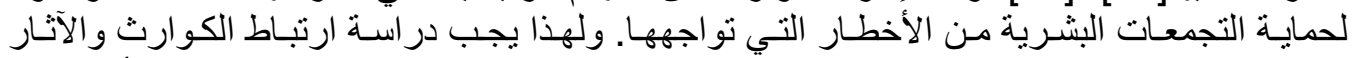

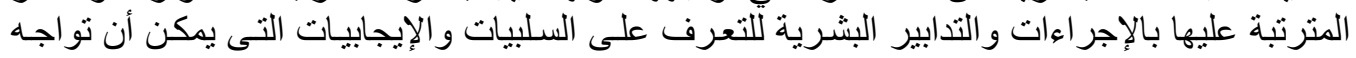

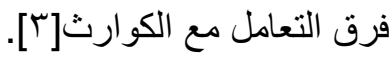

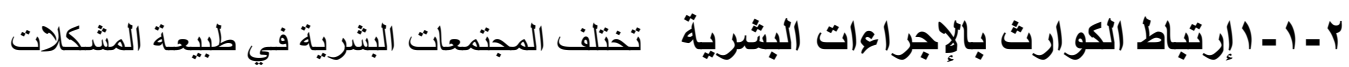

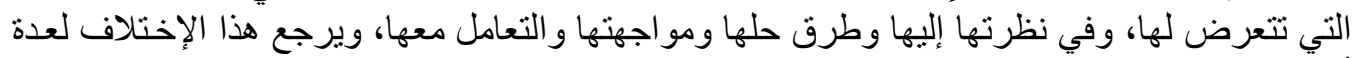

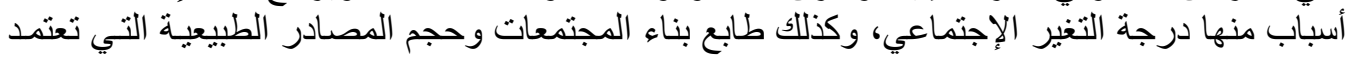

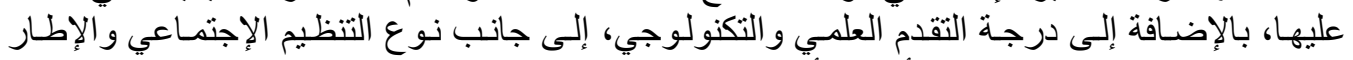

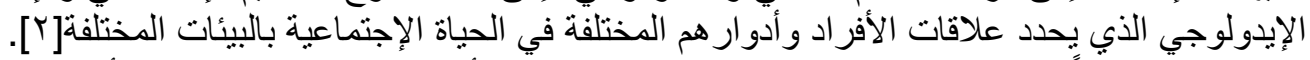

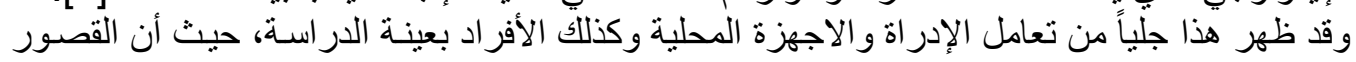

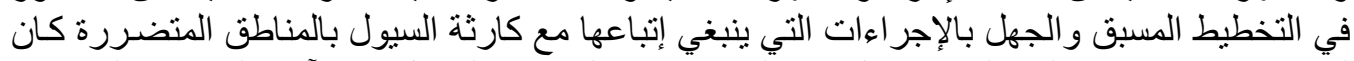

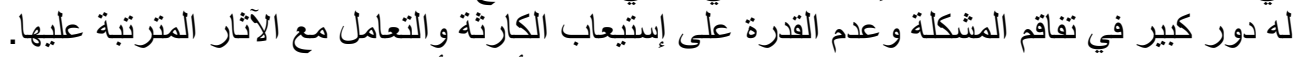

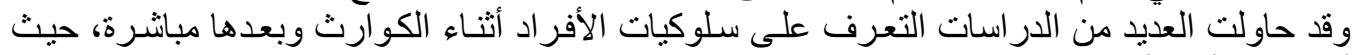

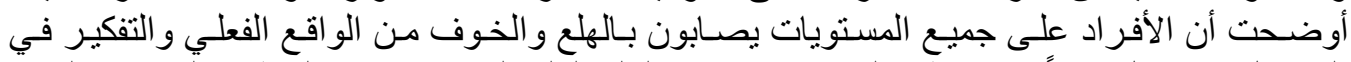

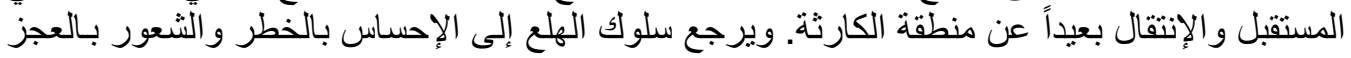

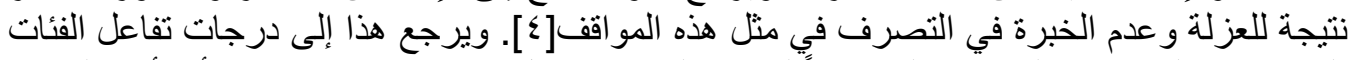

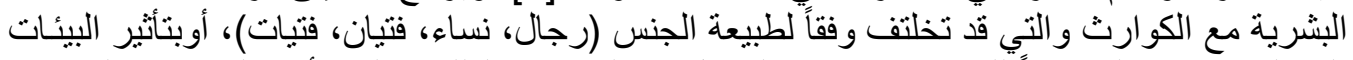

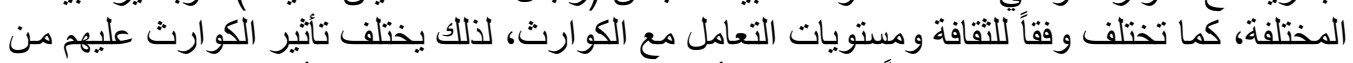

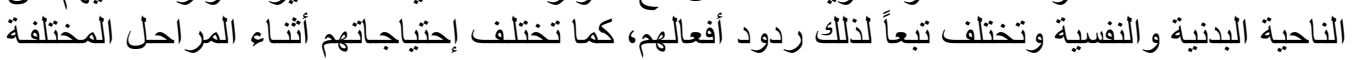

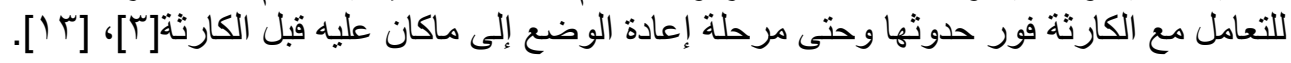

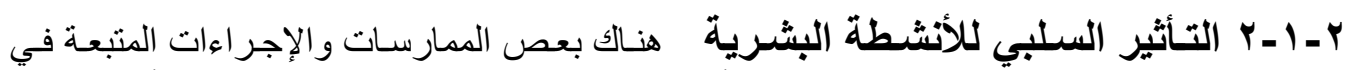

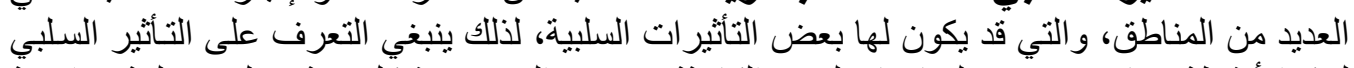

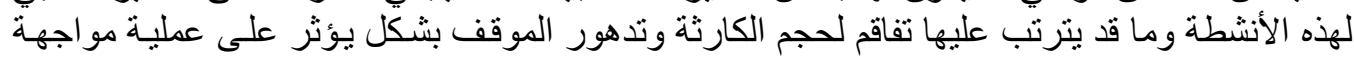

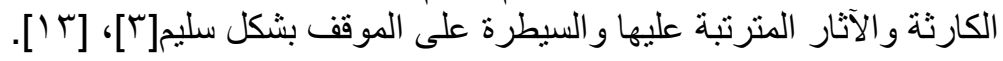




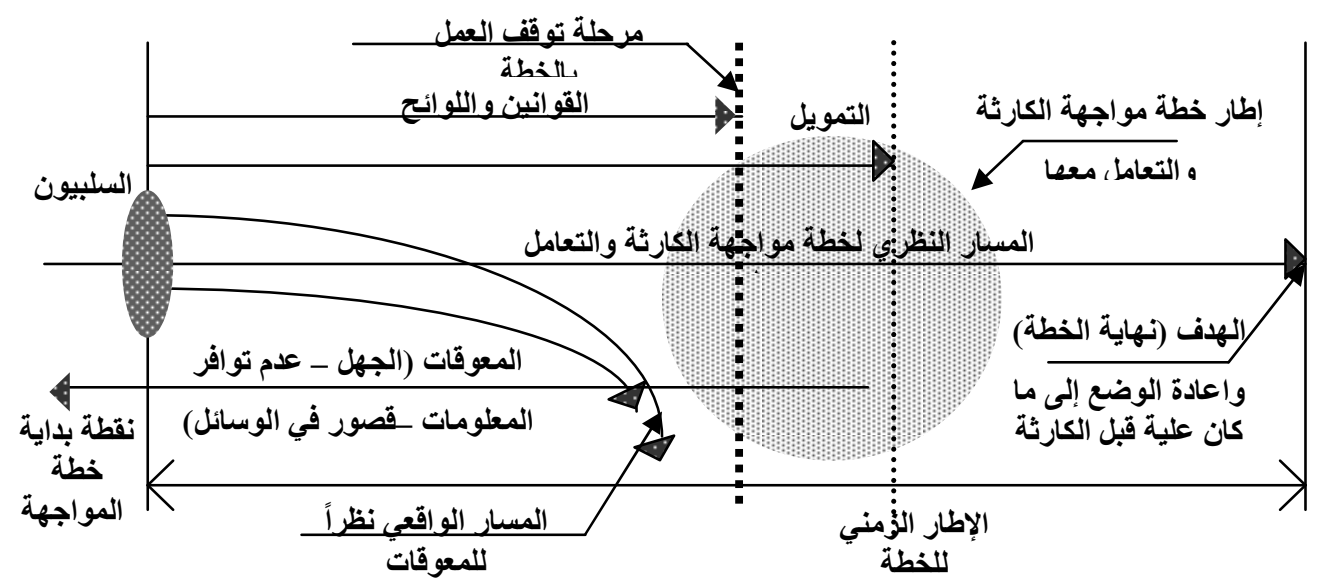

شكل (r) التأثير السلبي لتعارض جهود الأطراف المشاركة في خطط مواجهة الكوارث[ • 1]

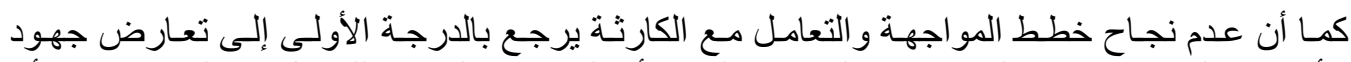

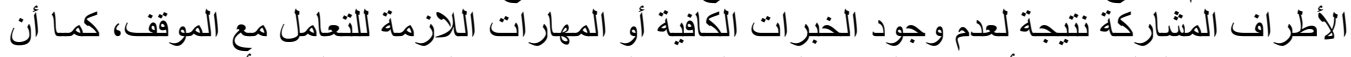

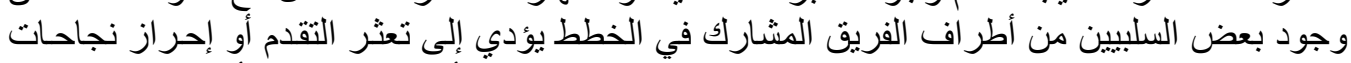

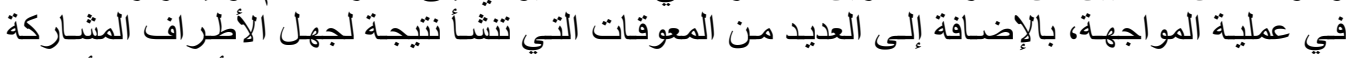

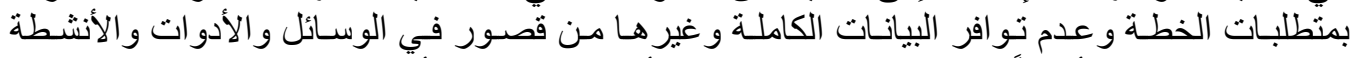

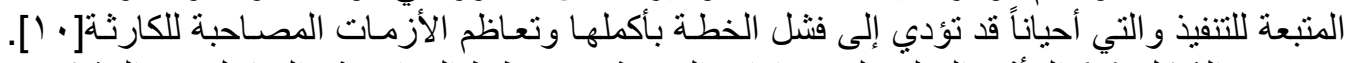

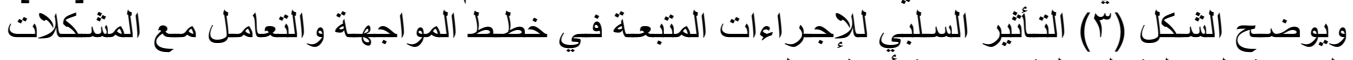

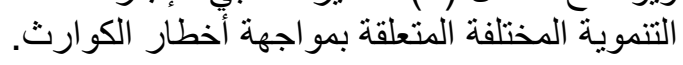

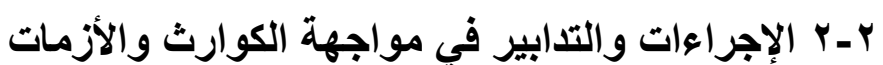

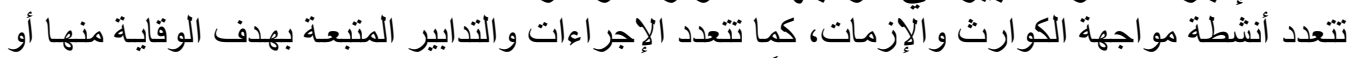

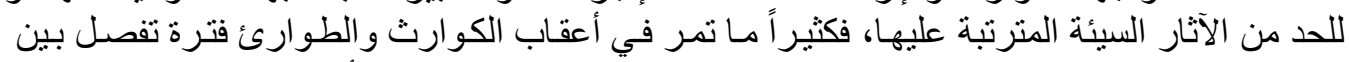

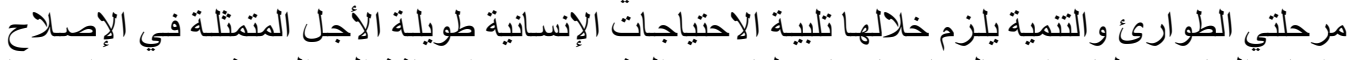

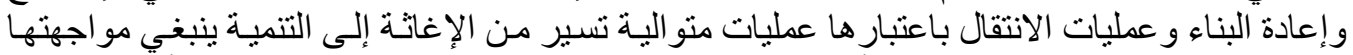

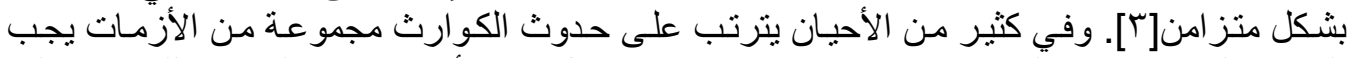

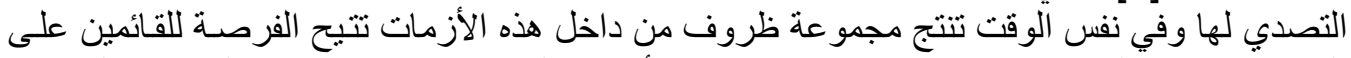

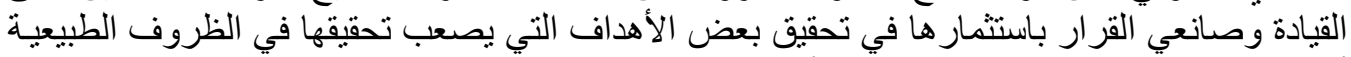

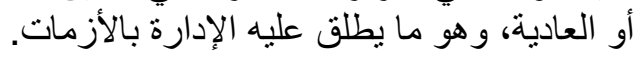

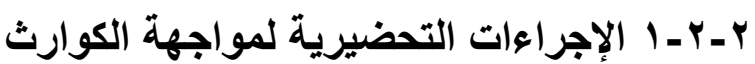

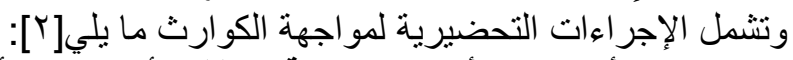

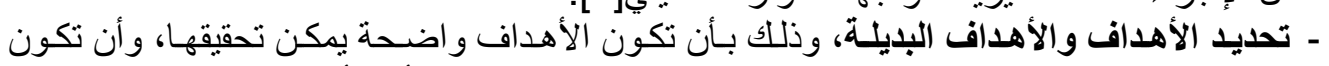

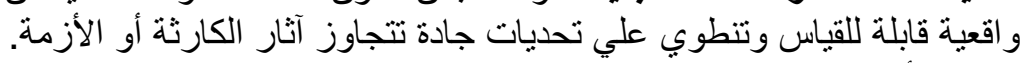

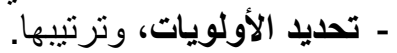
- ت تحديد الوسائل و المعايير المستخدمة في التقيبيم.

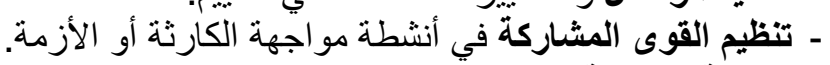
- الحركة السريعة والمبادرةً. 


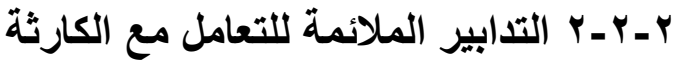

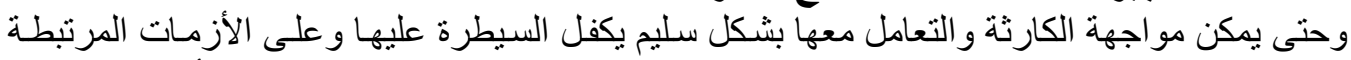

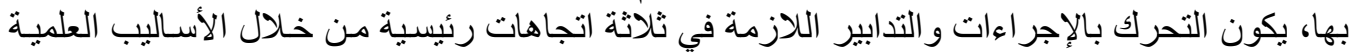

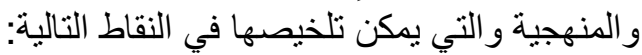

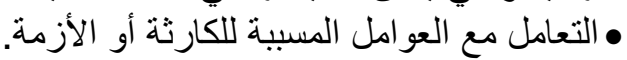

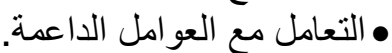

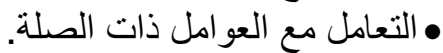

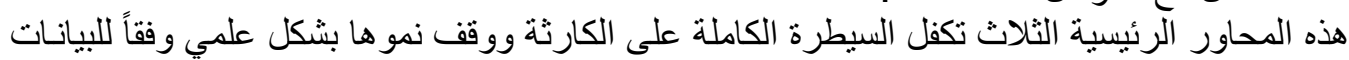

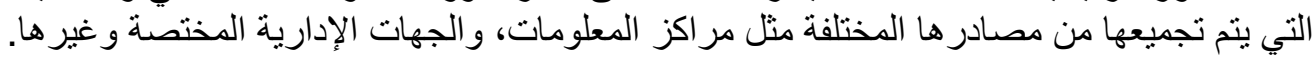

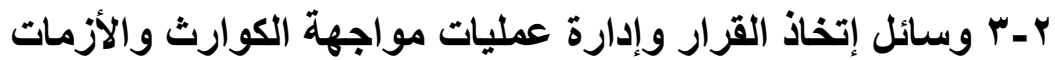

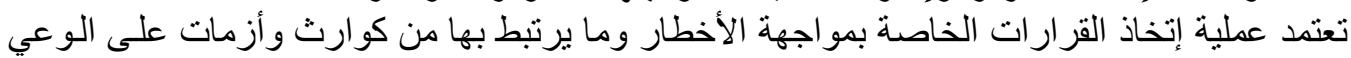

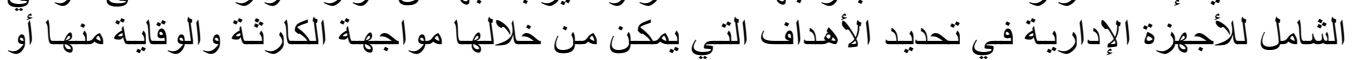

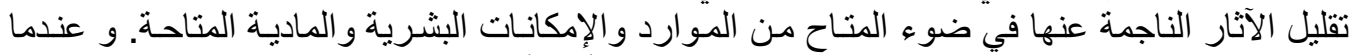

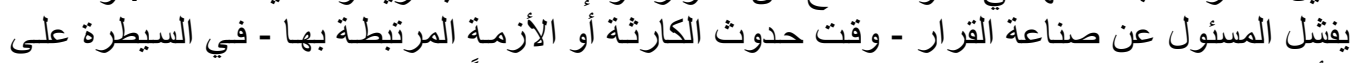

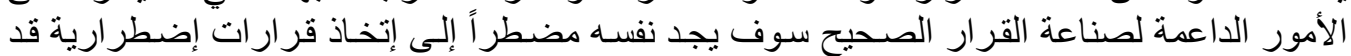

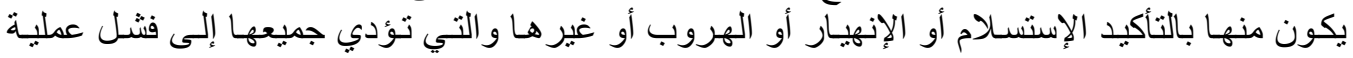

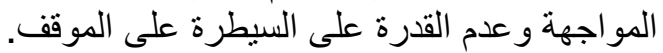

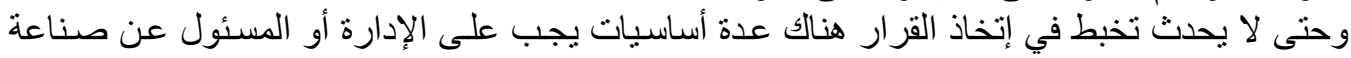

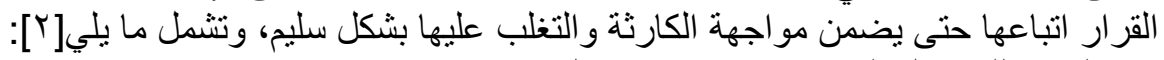

$$
\begin{aligned}
& \text { - السعي للوصول إلى هدف محدد من خلال تصرف الإن إيجابي. }
\end{aligned}
$$

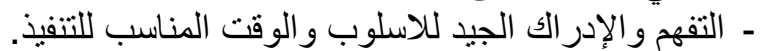

$$
\begin{aligned}
& \text { - الإستخدام السريع لمهارة التحليل و التقييم و التفضيل. }
\end{aligned}
$$

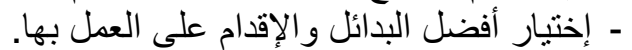

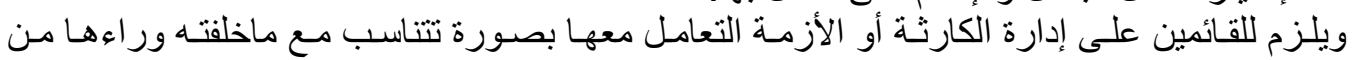

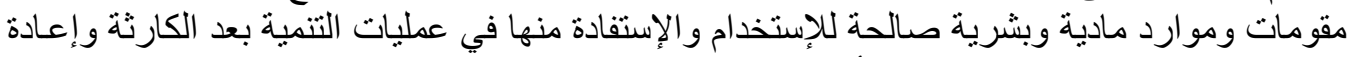
الموقف إلى ما كان عليه قبل الكارثة أو افضلة لإنلخ.

\section{r- المداخل المختلفة للتعامل مع الكوارث والأزمات المرتبطة بهات الماتهات}

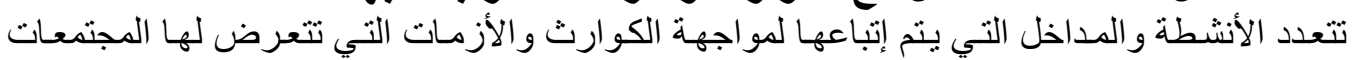

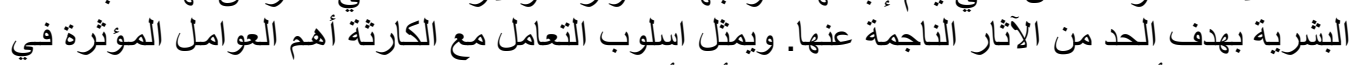

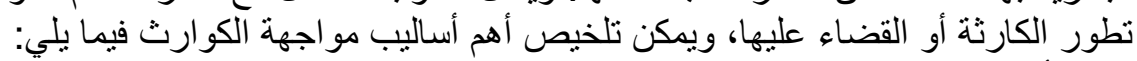

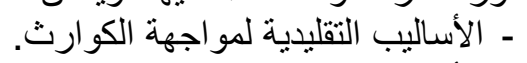

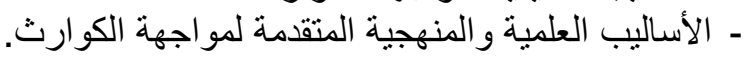

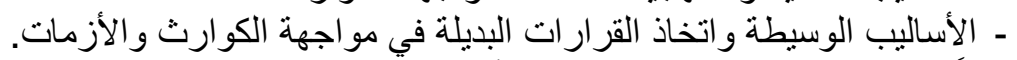

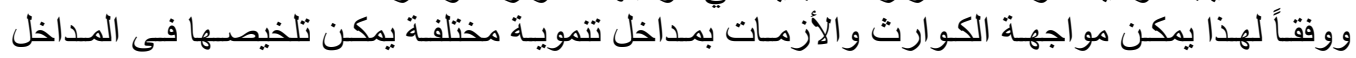

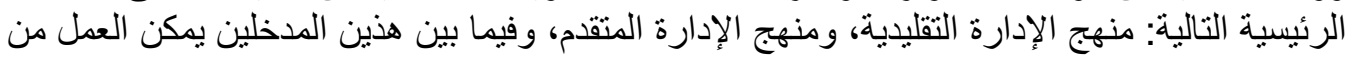

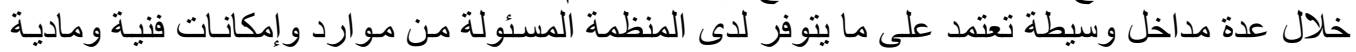

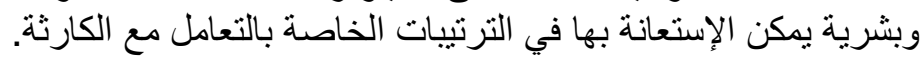

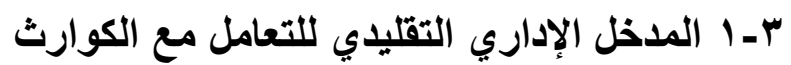

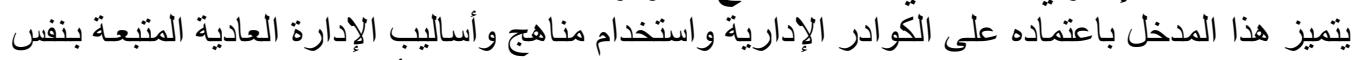

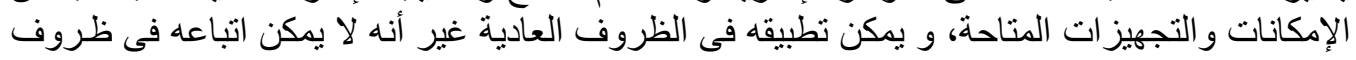


طارئة مشابهة للظروف التى تحيط بمو اجهة الكو ارث بما تحتويه من متغير ات عديدة ومتشـابكة، فضلاً

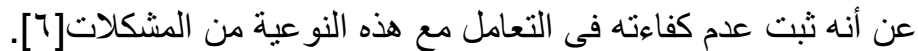

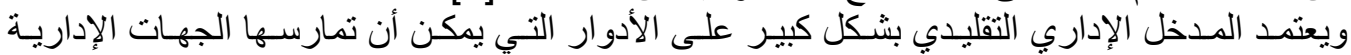

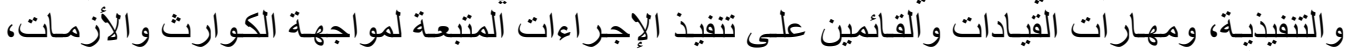

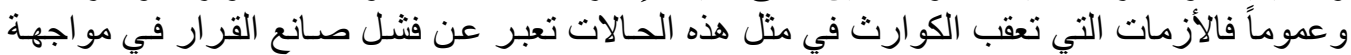

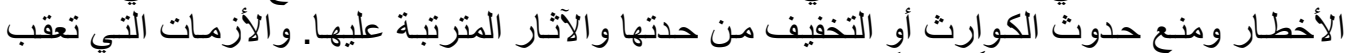

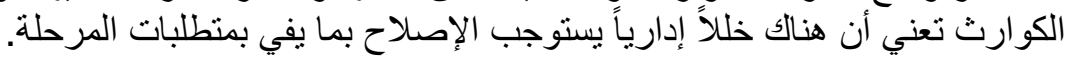

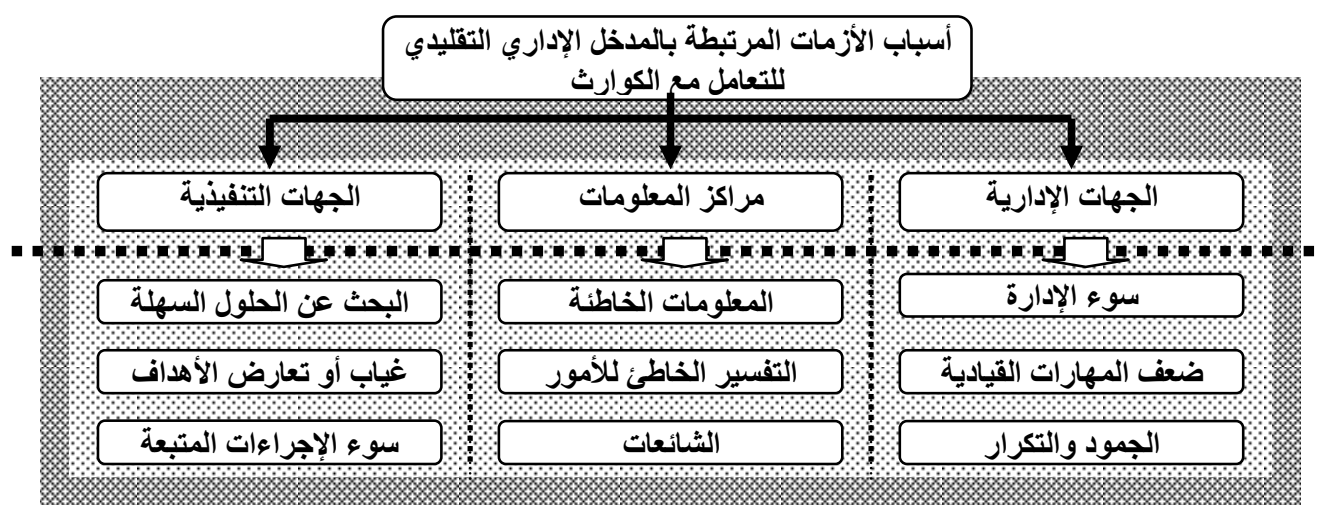

شكل ( ) أسباب الأزمات المرتبطة بالمدخل الإداري التقليدي للتعامل مع الكوارث[ [ 1] ]

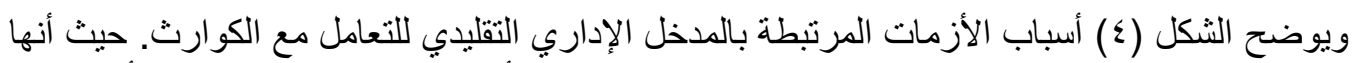

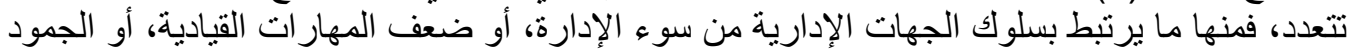

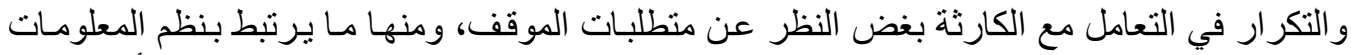

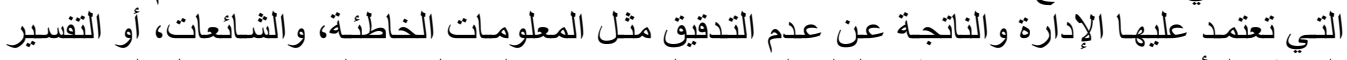

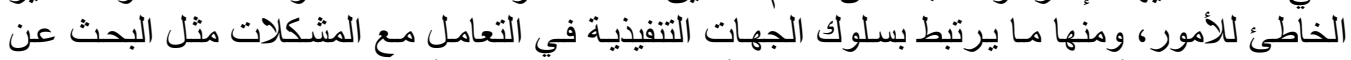

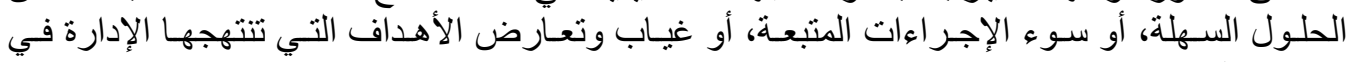

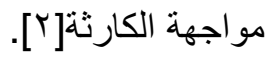

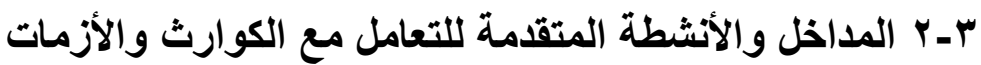

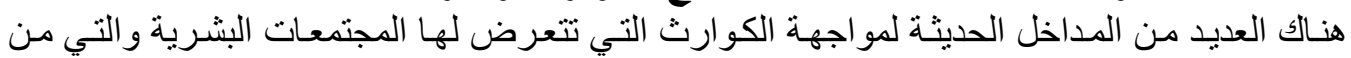

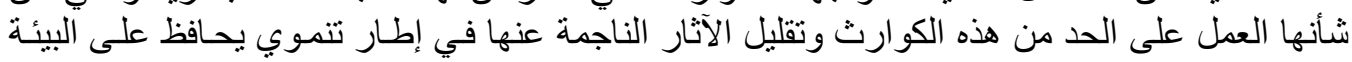

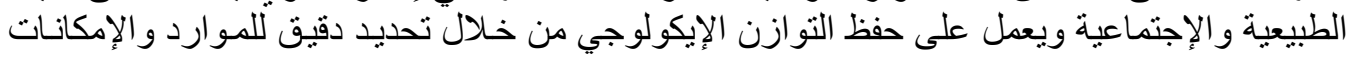

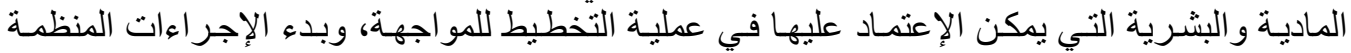

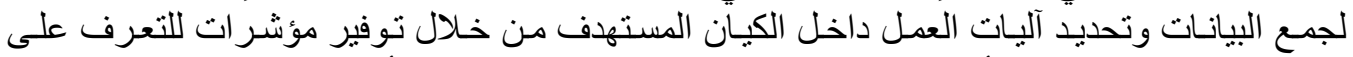

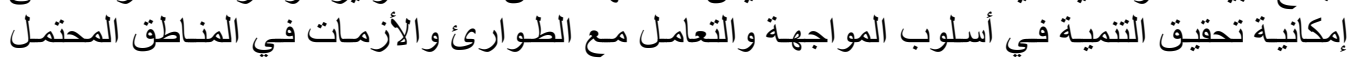

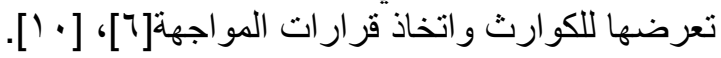



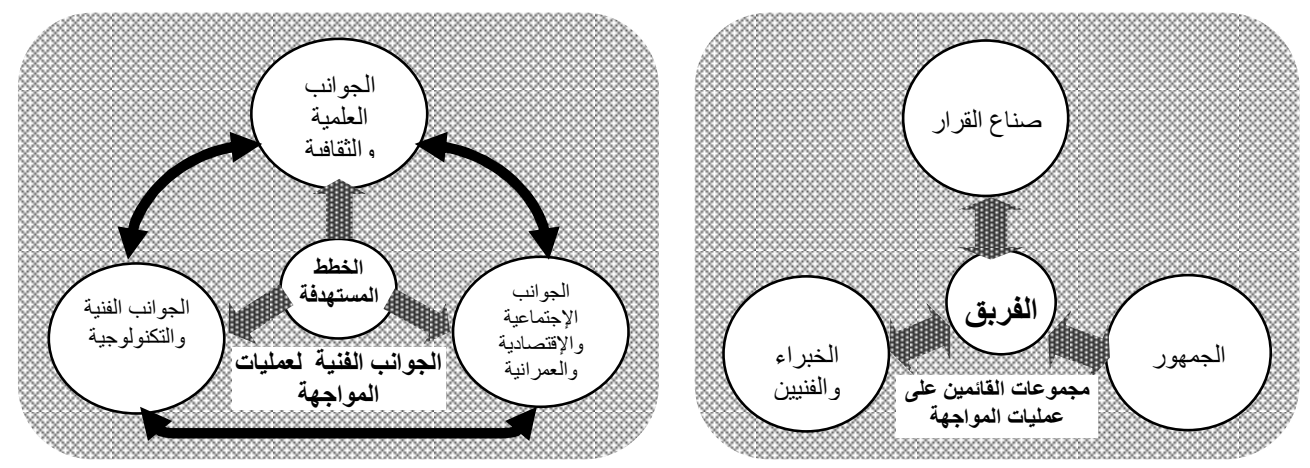

شكل (0) الأطراف المشاركة والجوانب المختلفة لعمليات التخطيط لمواجهة الكوارث[ • 1]

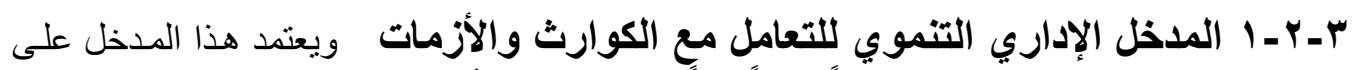

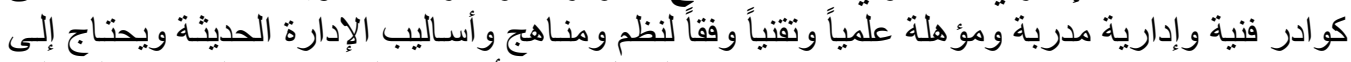

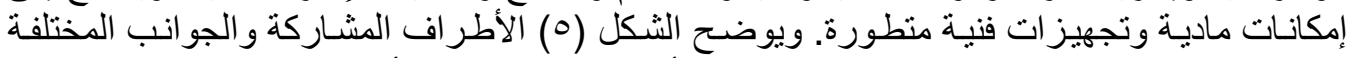

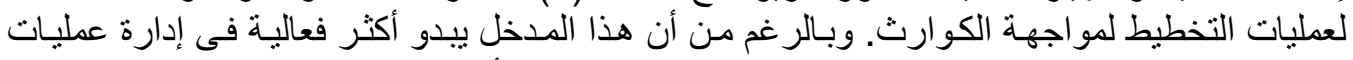

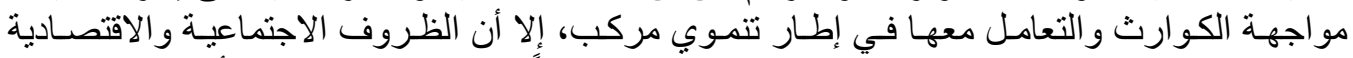

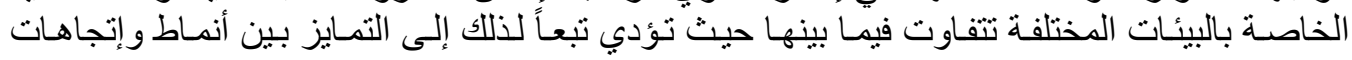
التفكير في عمليات المو اجهة و التعامل مع الكوارث فئن في كلن بيئة.
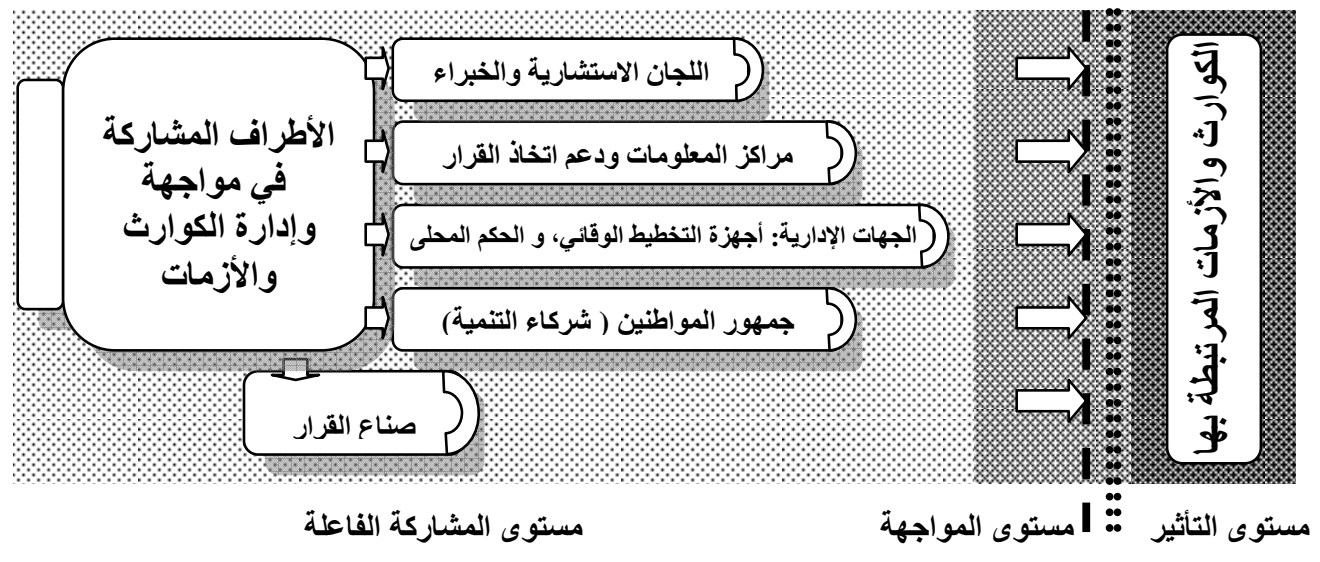

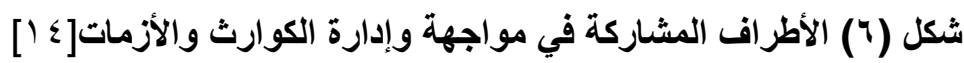

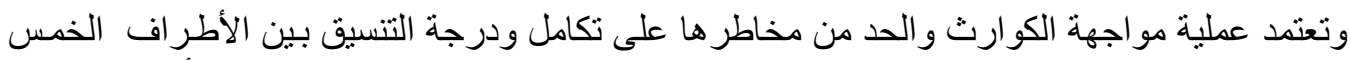

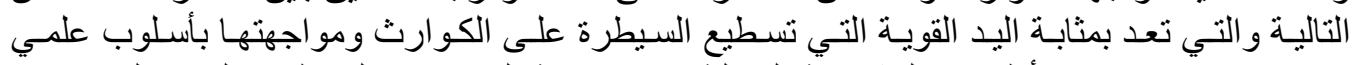

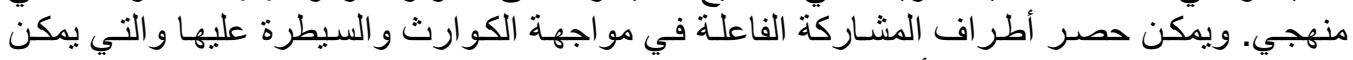

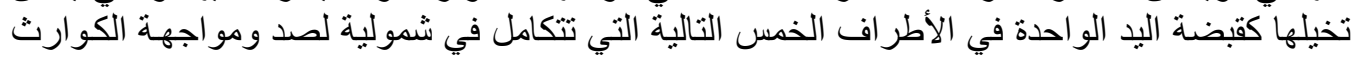

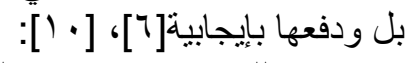
اللجان الاستشارية و الخبر اءو و المتخصصين.

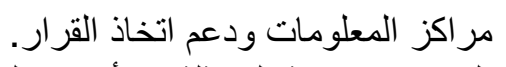
الجهات الإدارية المنمثلة في أجهزة التخطيط الوقائي، وأجهزة الحكم المحلى. 


$$
\text { • • }
$$

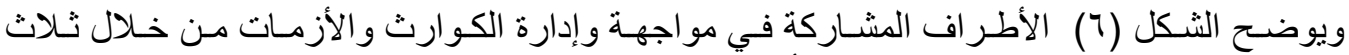

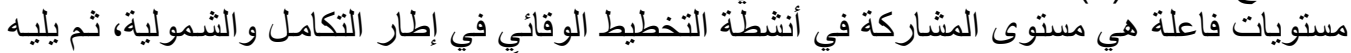

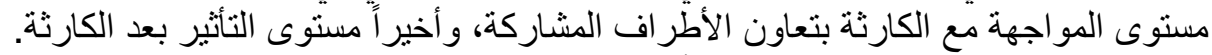

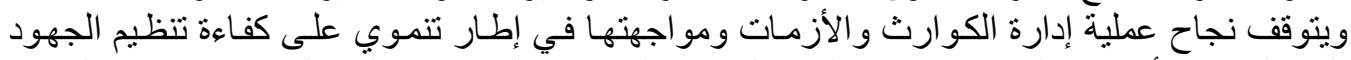

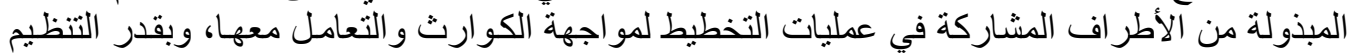

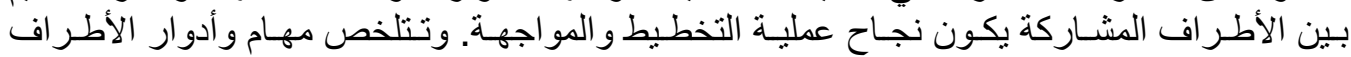

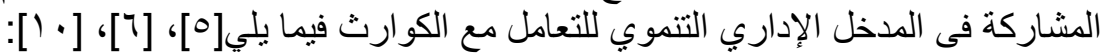

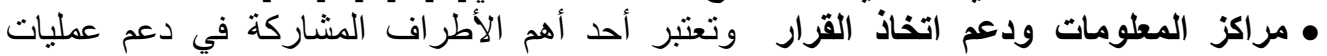

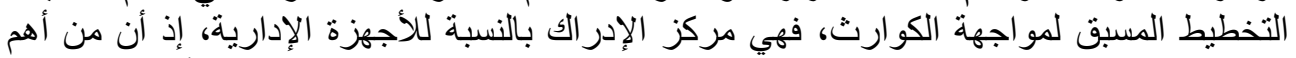

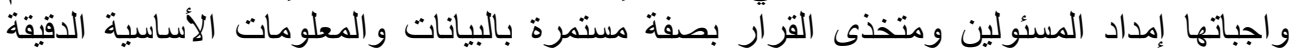

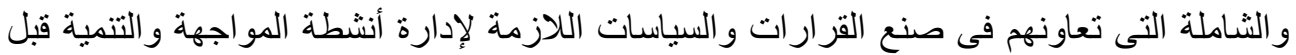

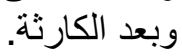

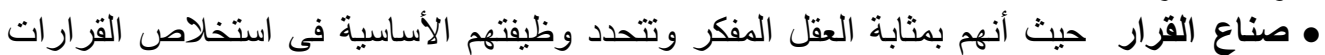

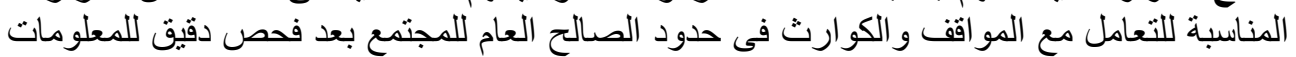

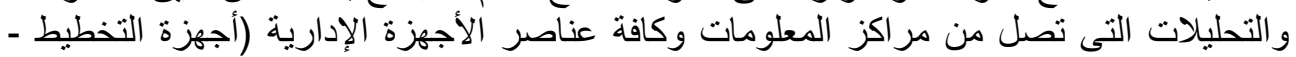

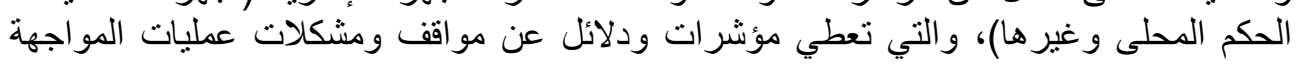

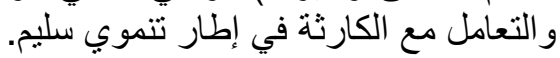

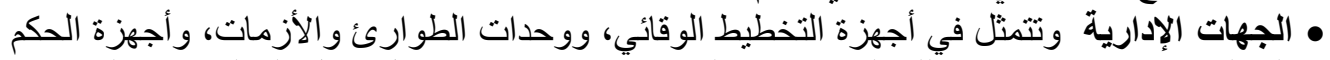

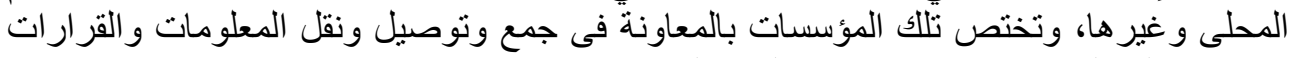

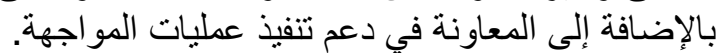

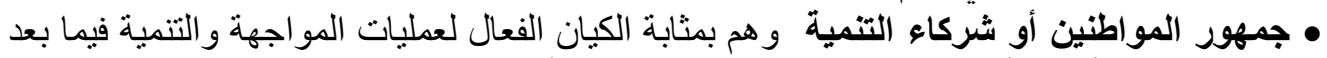

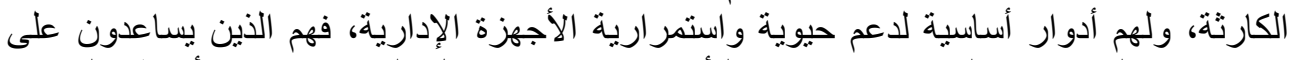

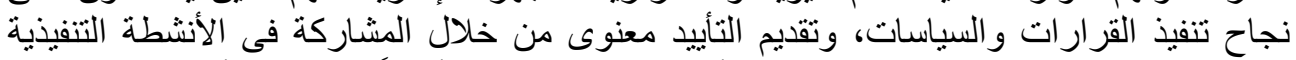

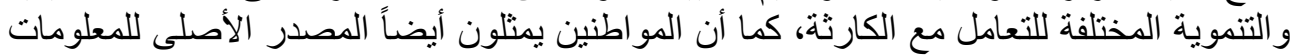

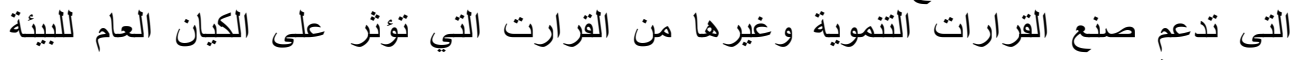

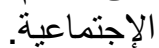

• اللجان الإستثارية والخبراء والمتخصصين وتمثل دور أهل الخبرة، حيث أنهم بمثابة العنصر

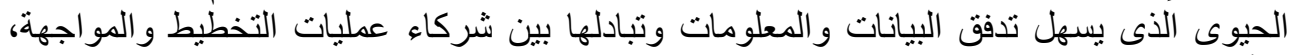

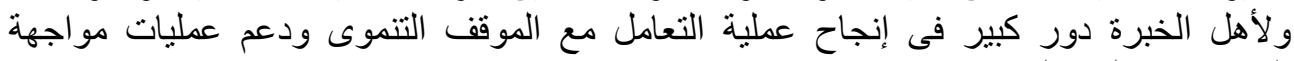

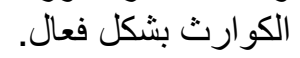

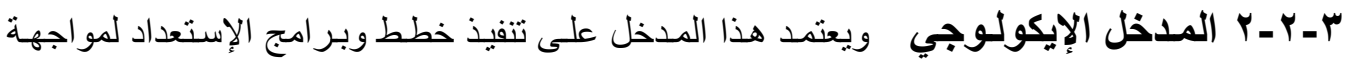

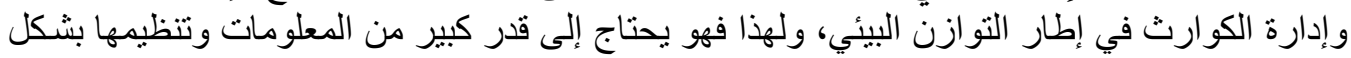

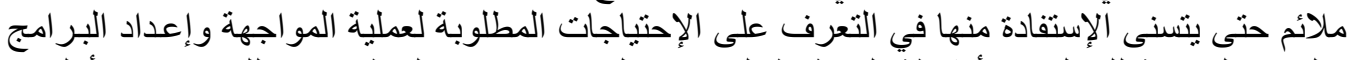

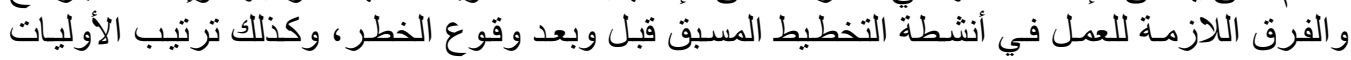

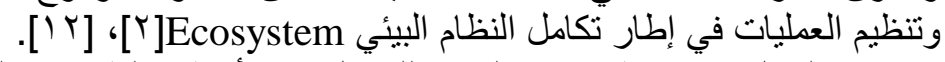

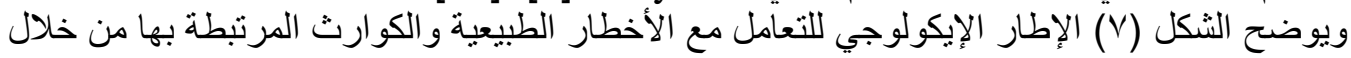

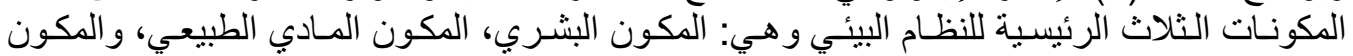

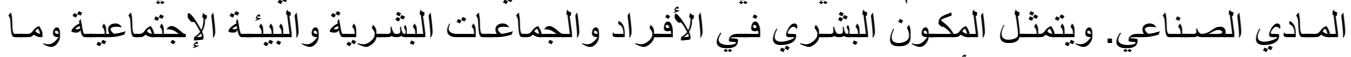

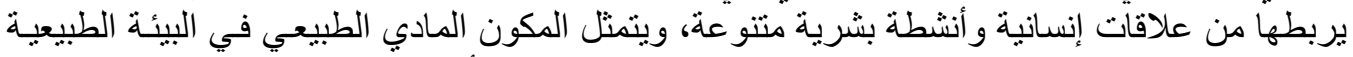
و البيئة المناخية والظو اهر الطبيعية وغيرها من العناصر الطبيعية، أما المكون المـادي الصني الصناعي فيتمثل 
في البيئة الماديـة المبنيـة و الألات التكنولوجيـة والمـواد المصنعة و غيرهـا مـن العناصـر التي استحدثها

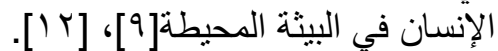

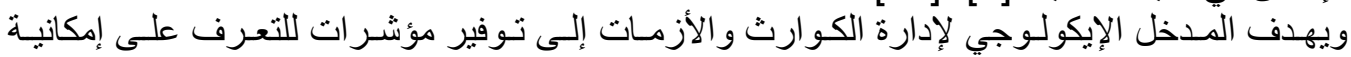

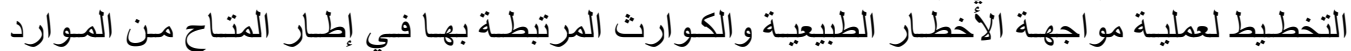

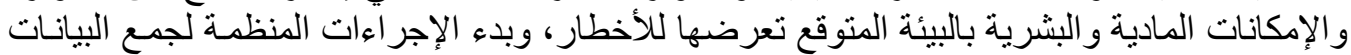

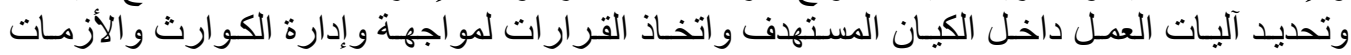

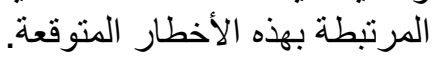

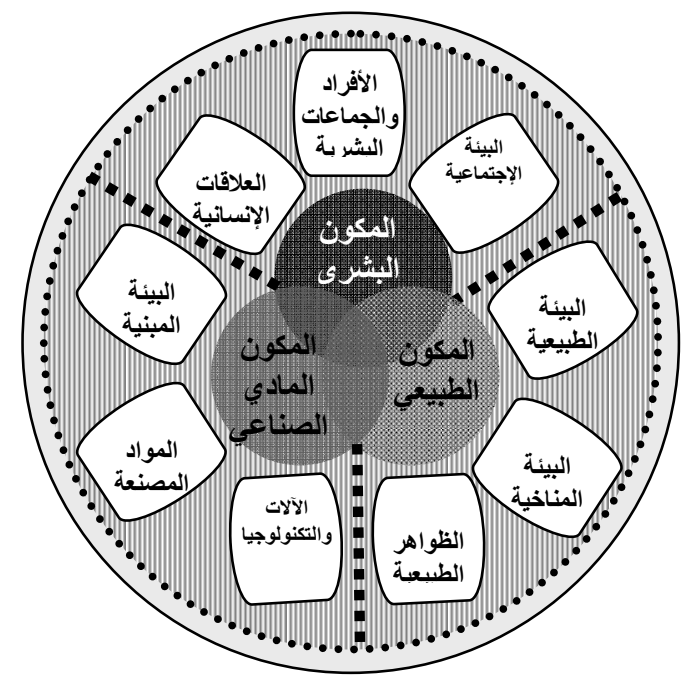

شكل (V) الإطار الإيكولوجي للتعامل مع الأخطار الطبيعية والكوارث المرتبطة بها]ع 1]

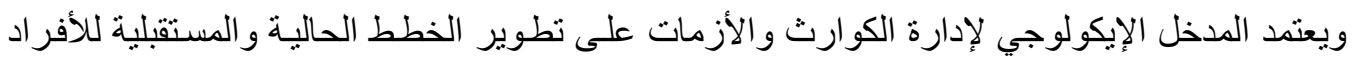

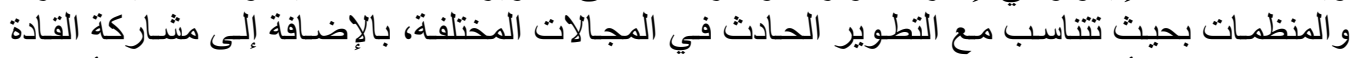

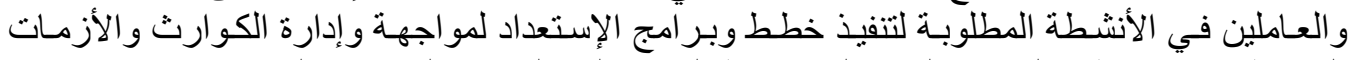
المرتبطة بها في إطار التوازن البيئي الذي يحفظ العلاقة التكاملية بين المكونات الثيذ الثلاث.

\section{ع - إستراتيجيات المواجهة والتعامل مع الكوارث والأزمات}

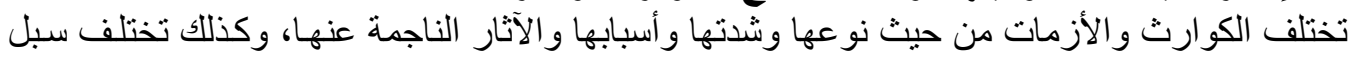

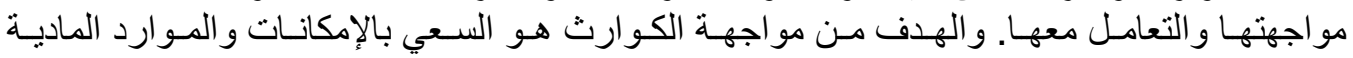

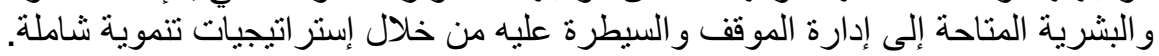

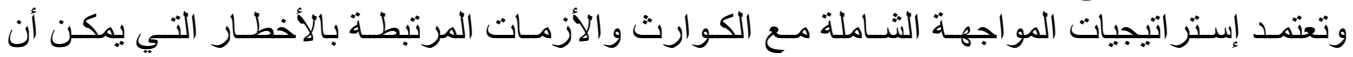

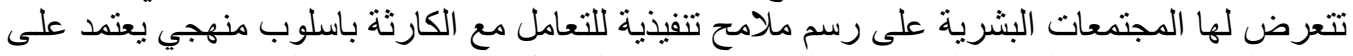

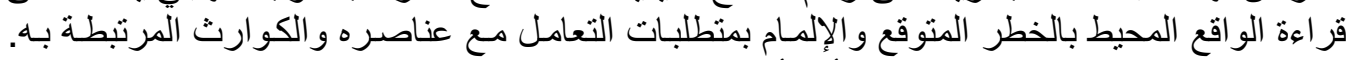

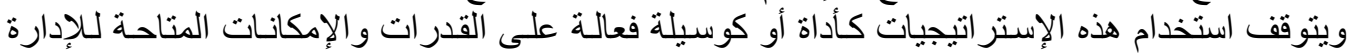

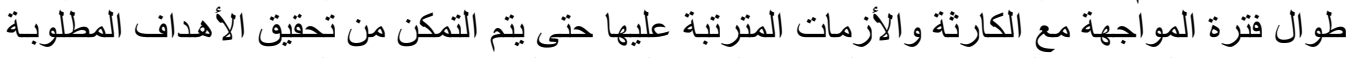

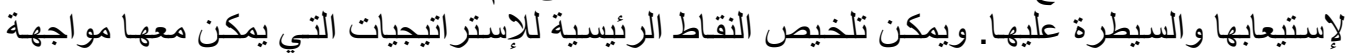




\section{ـ ـ استر اتيجية وقف النمو}

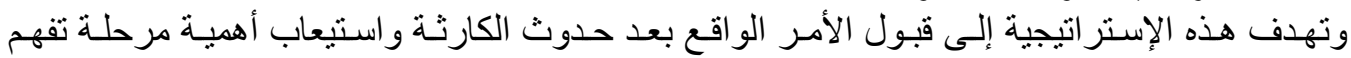

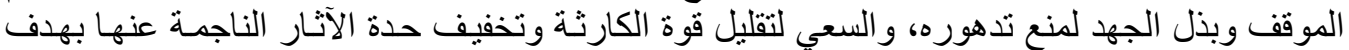

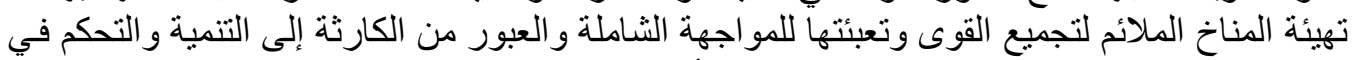

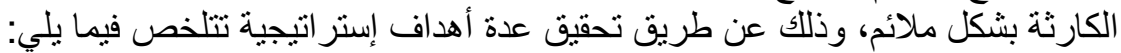
- م - مقف التدهور و الخسائر.

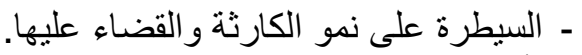
ـ - تأمين وحماية العناصر ذات العات القيمة المادية والحضاه العارية.

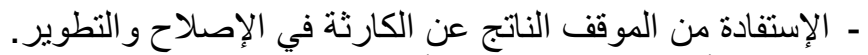

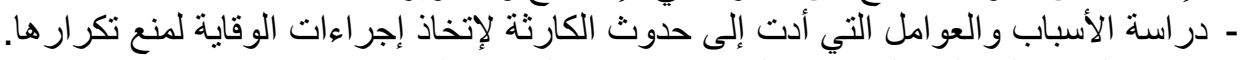
- تحقيق التنمية الثاملة و النهوض بالبيئة الإجتماعية لمنطقة الكارثة.

\section{ع - r استر اتيجية التجزئة}

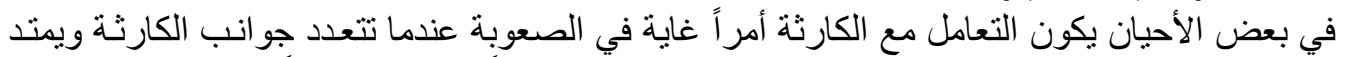

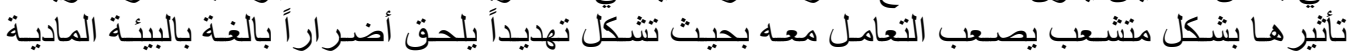

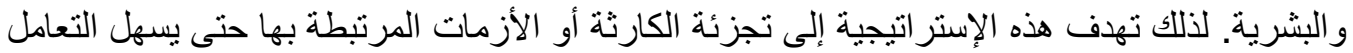

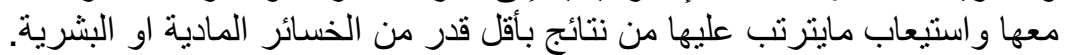

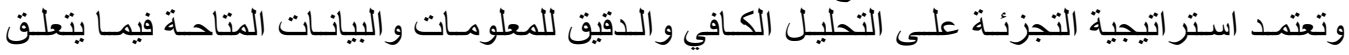

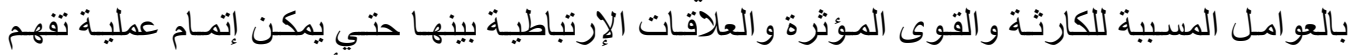

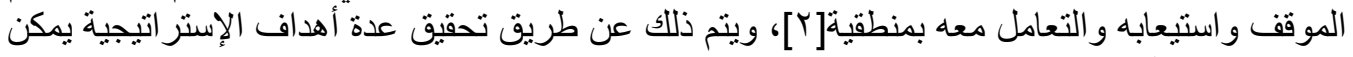

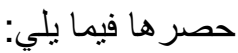
ـ - التحليل الكافي و الدقيق للمعلومات وات والبيانات فيما يتعلق بالعو امل المسببة للكارثة.

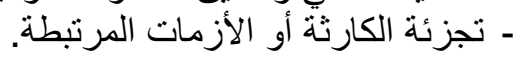

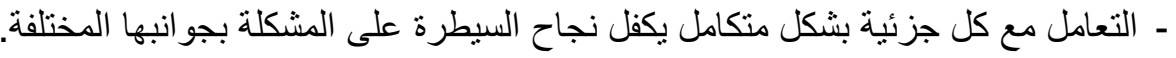

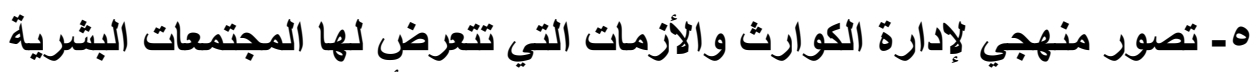

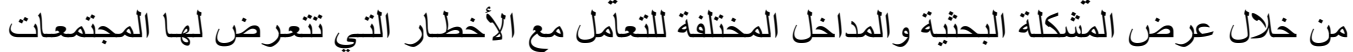

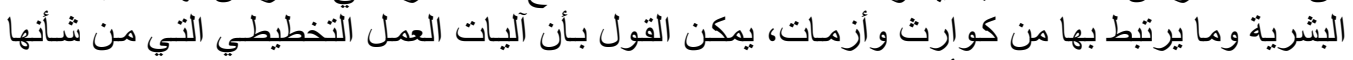

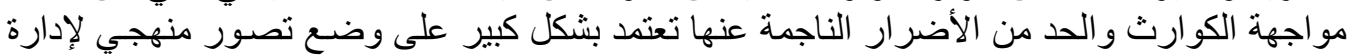

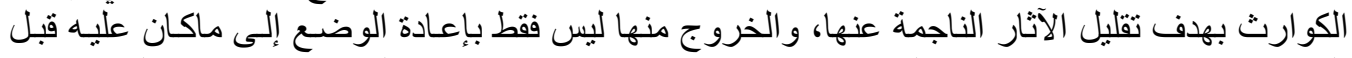

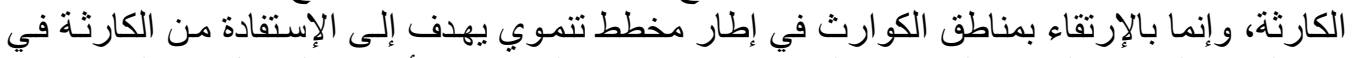

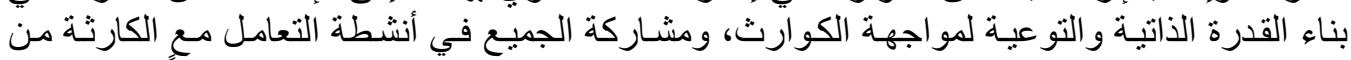

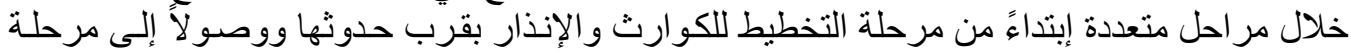

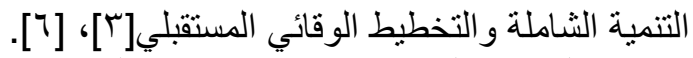

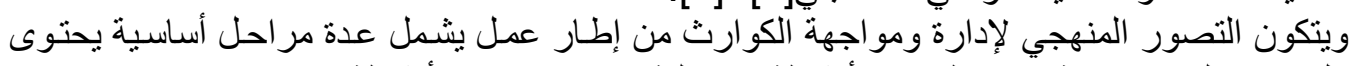

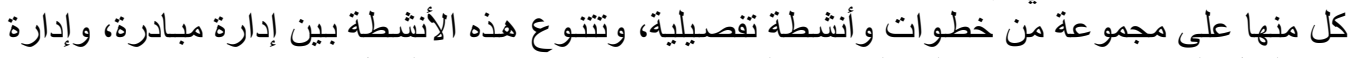

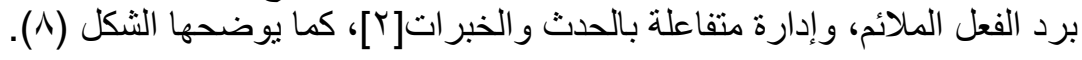

\section{هـ 1 المقومات الأساسية والهيكل التظيمي للمنهج المقترح لمواجهة الكوارث}

تعتمد المقومات الأساسية للمنهج المقترح لمو اجهة و إدارة الكوارث و الأزمات على ما يلي [ • 1]:

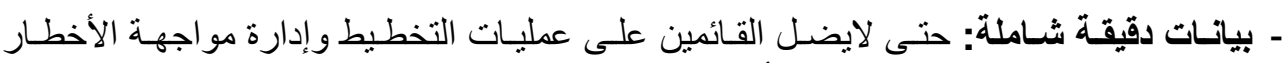
و الكو ارث المرتبطة بها بين القصور أو التقصير في فهم مر ادفات الخطة. 
ـ الواقعية: حتى لا تكون هنالك مغالاة تؤدي إلى إتخاذ قرار ات تستنزف الموارد الماديـة والبشرية

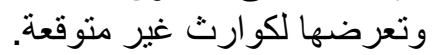

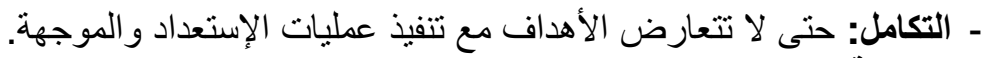

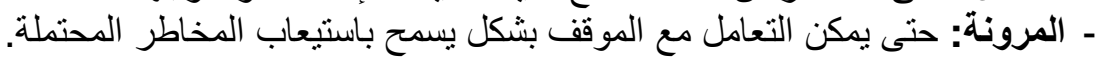

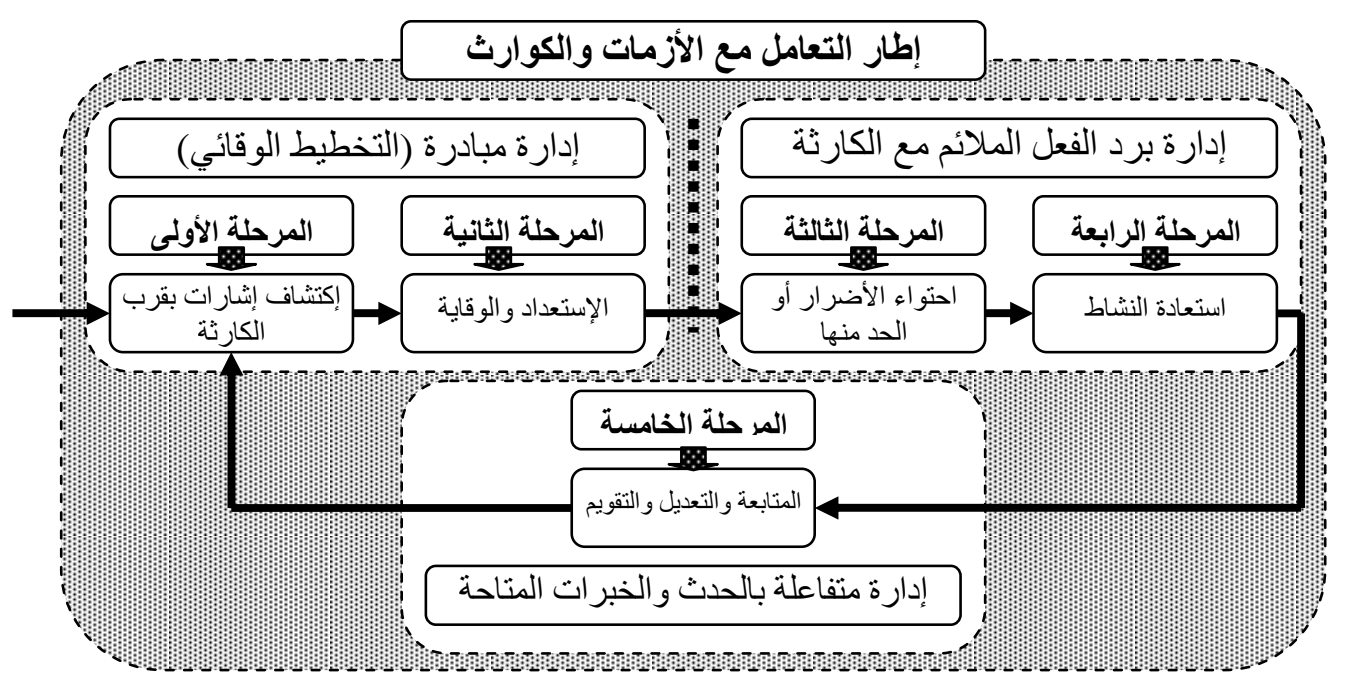

شكل (^) الإطار المنهجي للتعامل مع الكوارث والأزمات [؛ 1]

ويشمل الهيكل التظظيمي للمنهج المقترح لمو اجهة وإدارة الكوارث و الأزمـات الثكل (9) سلسلة متتابعـة

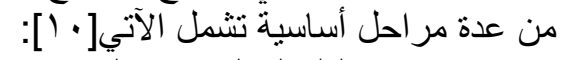

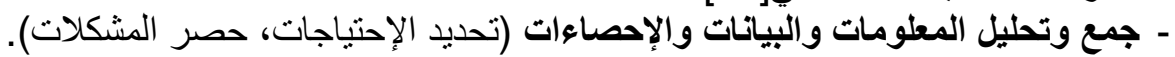

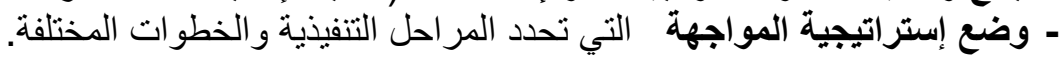

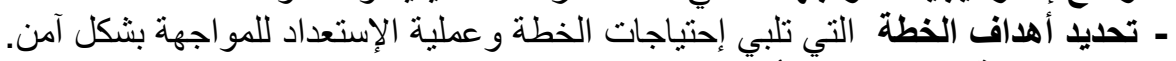

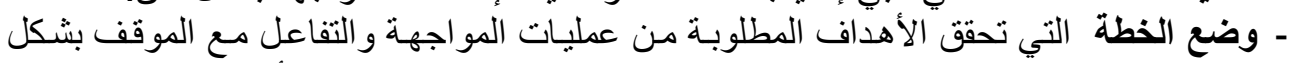

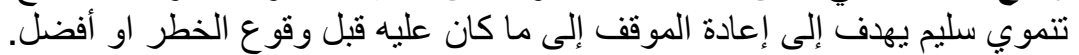

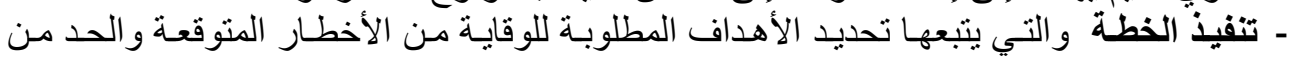

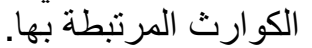

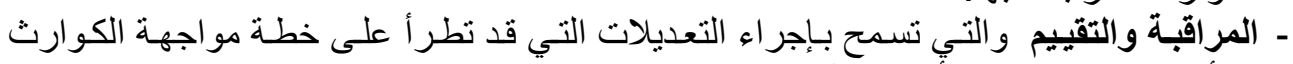

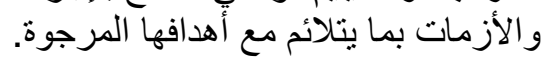




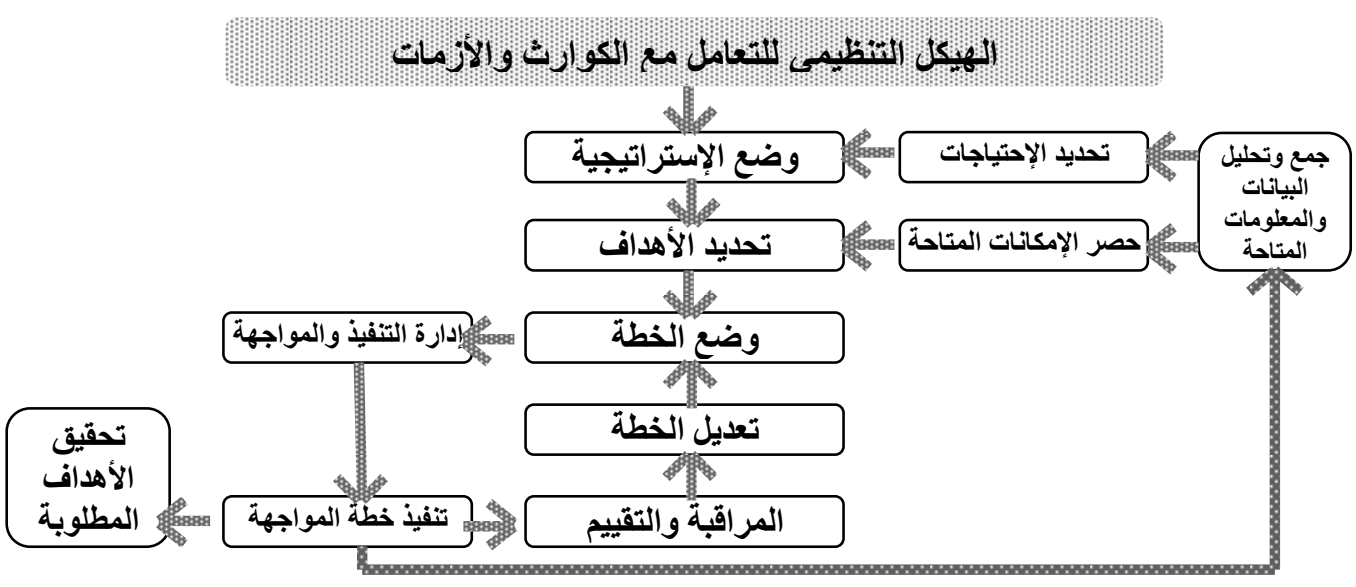

شكل (9) الهيكل التنظيمي للتعامل مع الكوارث والأزمات[ · [1]

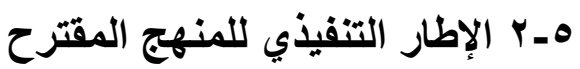

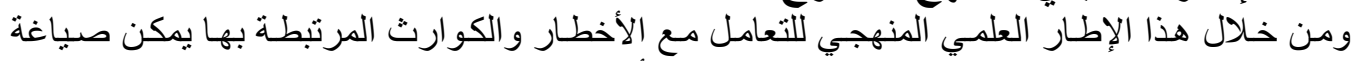

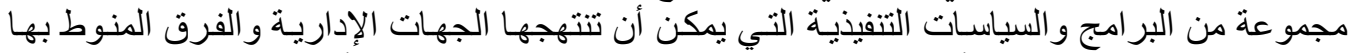

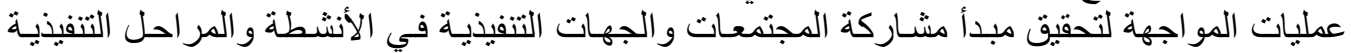

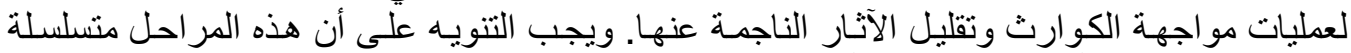

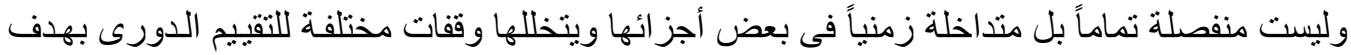

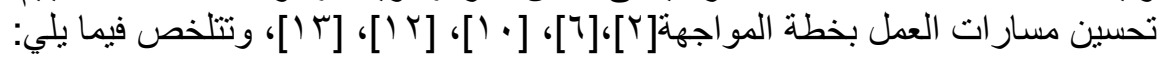

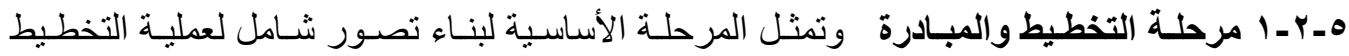

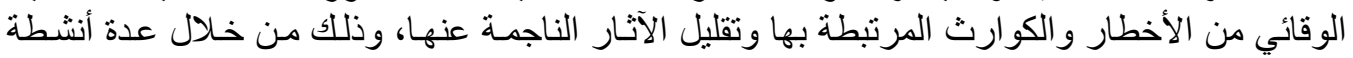

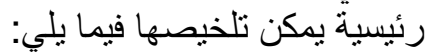

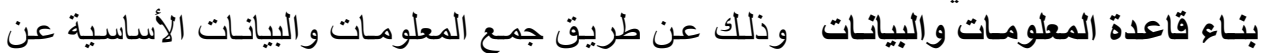

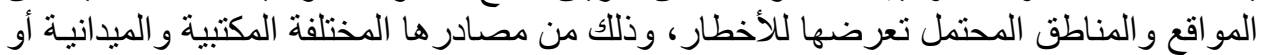

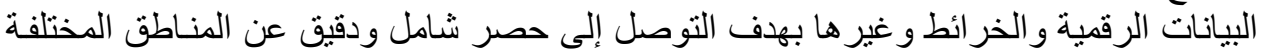

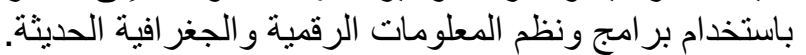

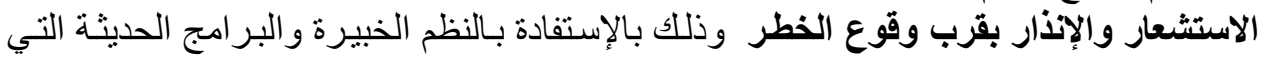

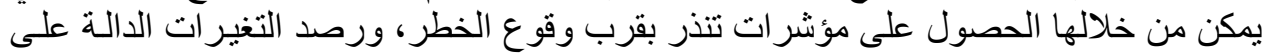
توقع حدوث خلل سواء ما يتعلق بالأخطار الطبيعية أو الأخطاء البش البشرية.

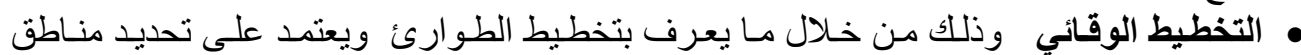

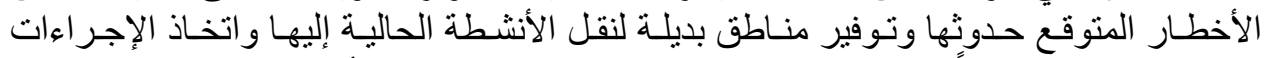

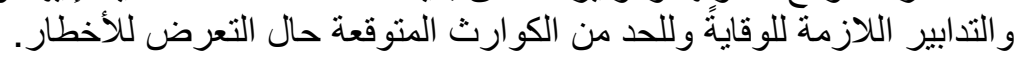

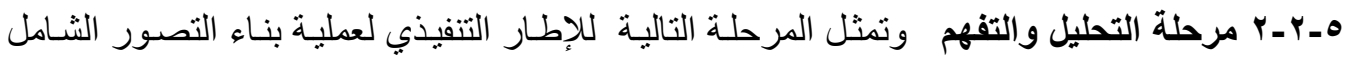

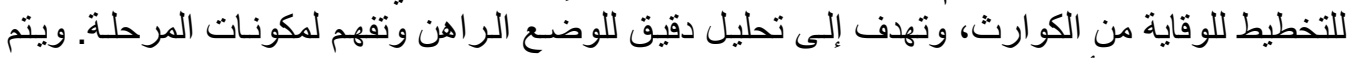

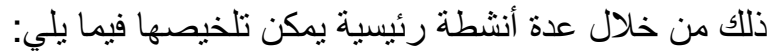

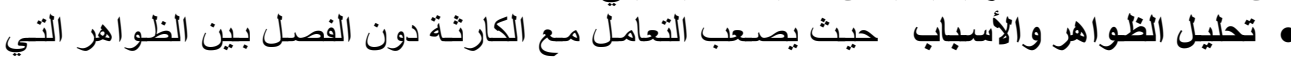

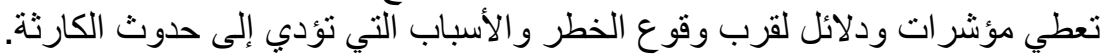




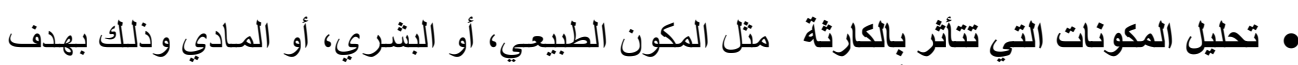

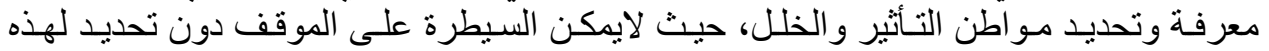

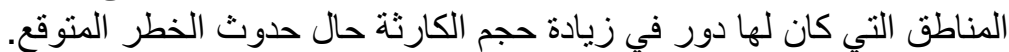

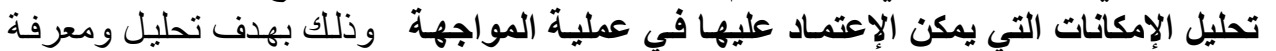

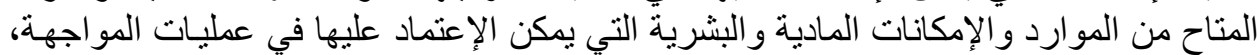

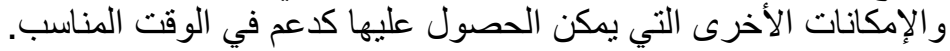

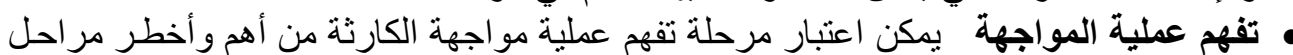

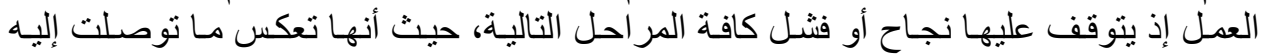
الإدارة من إلمام كامل بمتطلبات التعامل مع الموقف وإنخا إنخاذ الإجراءات و التدابير الداعمة لعمليات

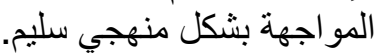

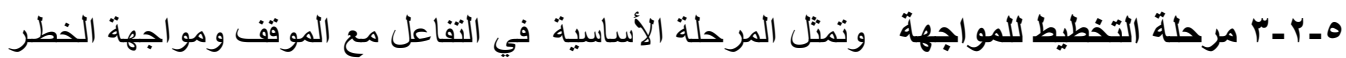

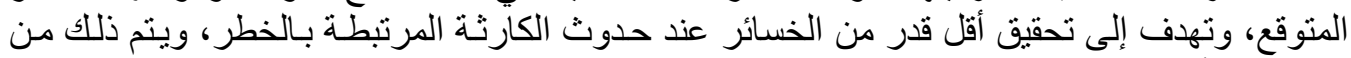

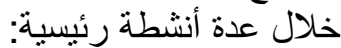

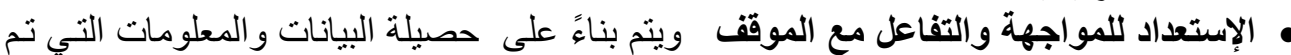

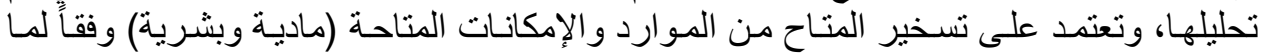

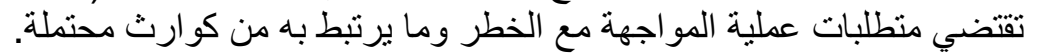

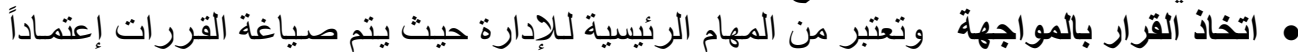

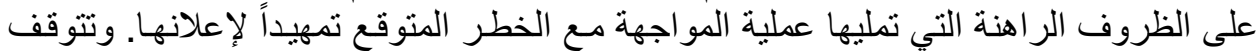

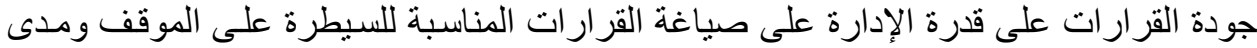

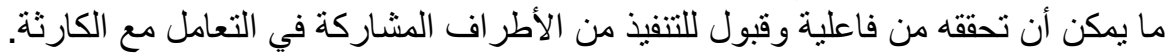

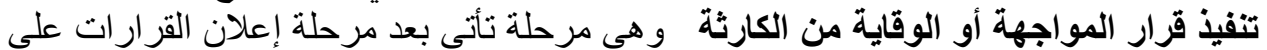

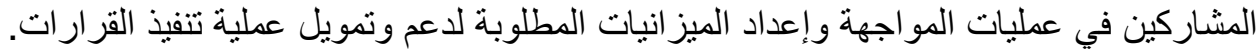

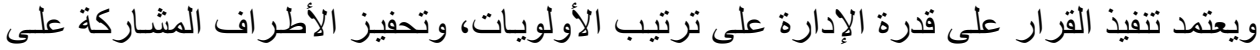

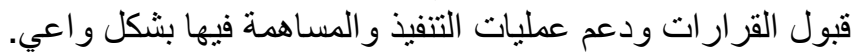

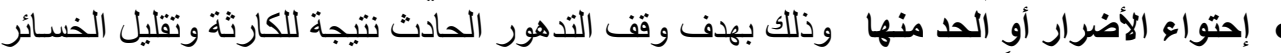

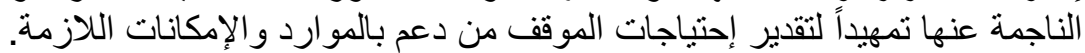

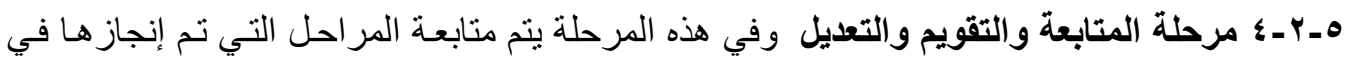

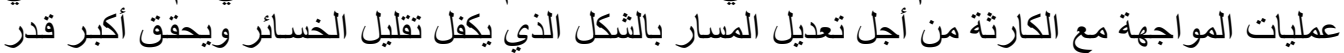
من المنفعة المادية والبشرية في التعامل مع الموقف، ويتم ذلك من خلال عدة أنشطة يمكن تلخيصها فئريا • تعديل المسار أثناء المواجهة وذللك باتخاذ القرارات التي تنتو ائم مع الإحتياجات الطارئة وتلبي

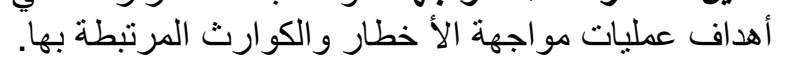
• تطوير الأداء واستحداث النظم وذللك من خلال اللجوء إلى اللى الأدوات الملائمة للتعامل مع الموقف

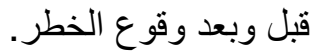

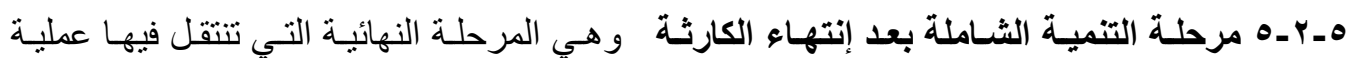

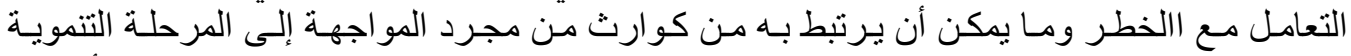

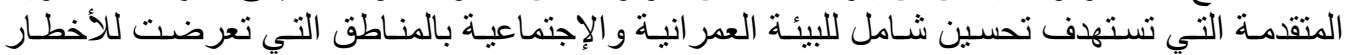

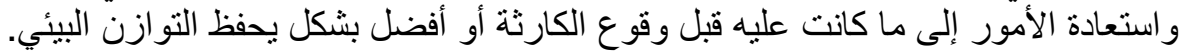


تعتبر إدارة الأزمات و الكو ارث أحد المهام الرئيسية للحماية من الكوارث أو للحد من آثار هـا. فالكوارث

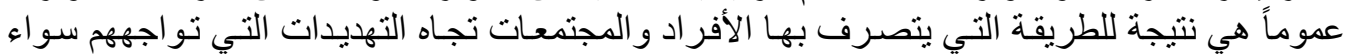

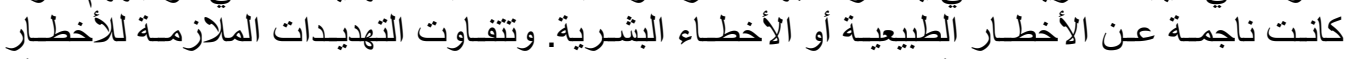

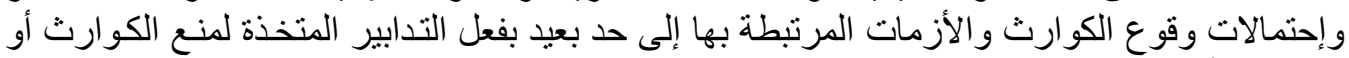

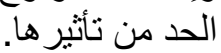

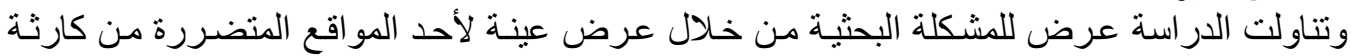

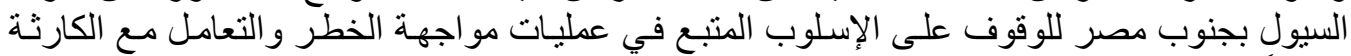

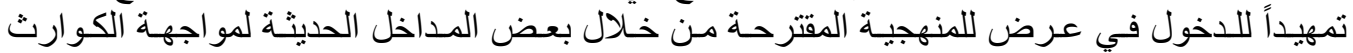

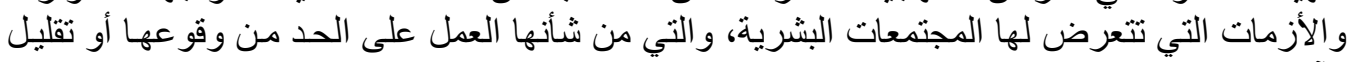

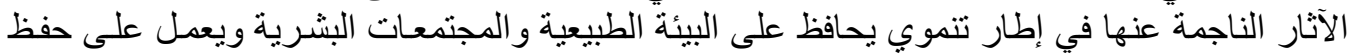

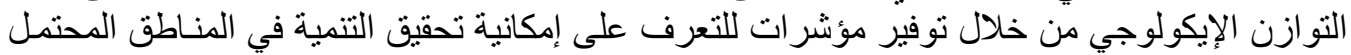

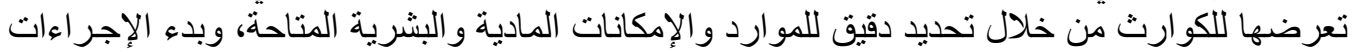

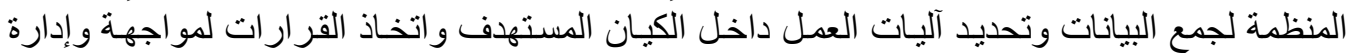

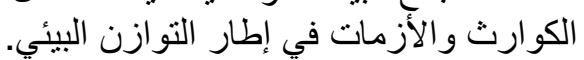

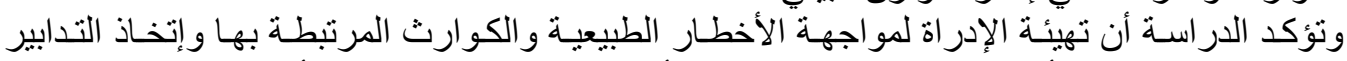

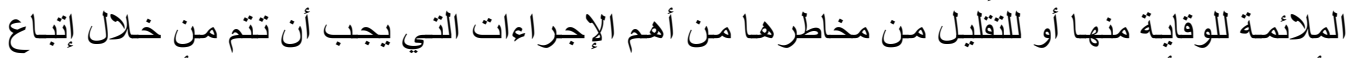

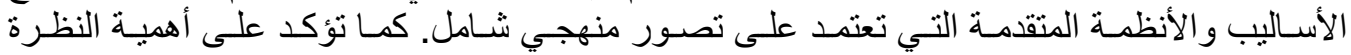

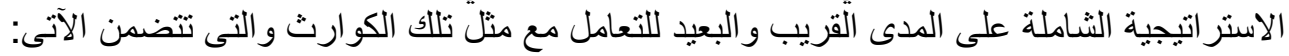

\section{على المدى القريب يجب إنباع الآتي:}

تحديد مو اقع المناطق المتوقع تعرضها للأخطار الطبيعية بالإعتماد على الأنظمة الحديثة للمعلومات

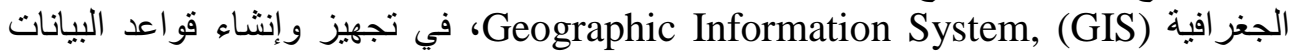

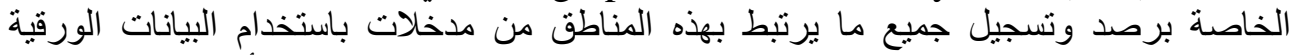

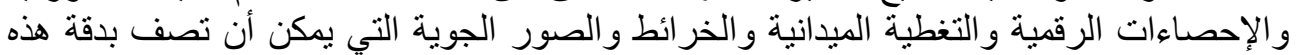

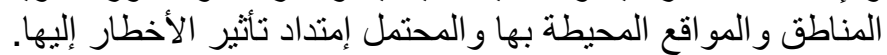

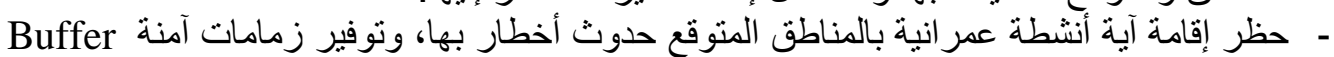
Zones

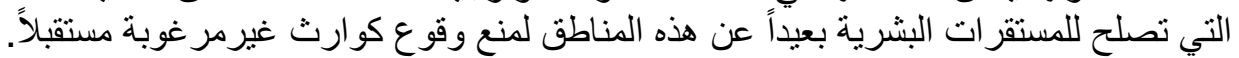

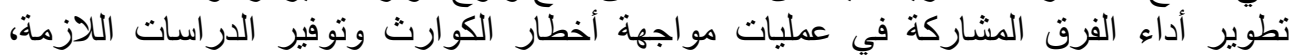

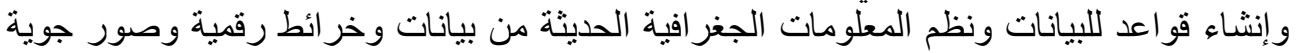

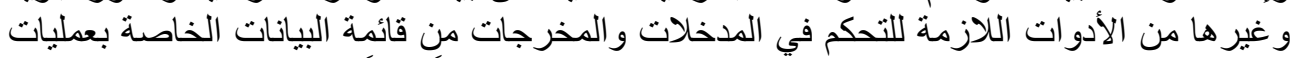
التحديد الجغر افي لمناطق الأخطار الطبيعية المنوقع حدوثها تحديداً دقيقاً.

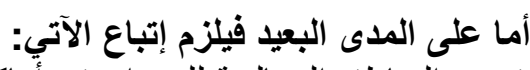

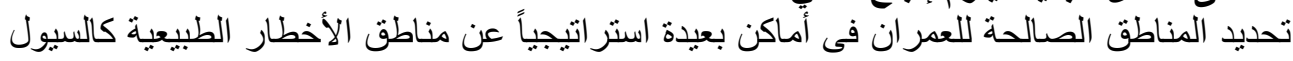

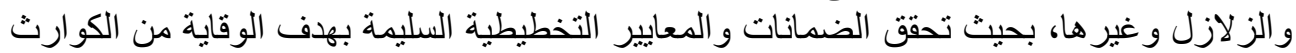

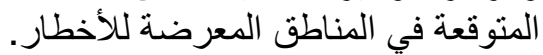

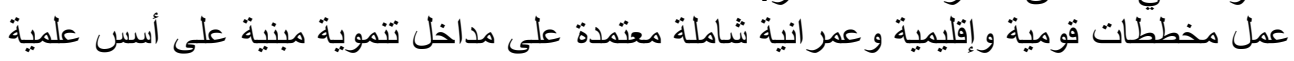

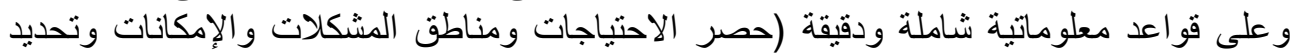

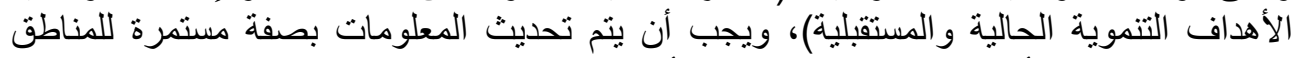

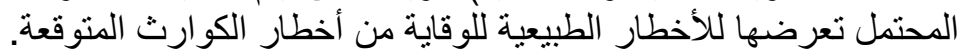

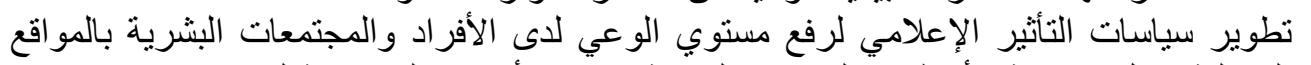

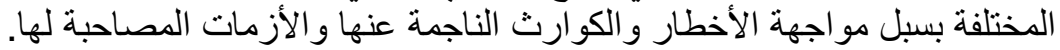




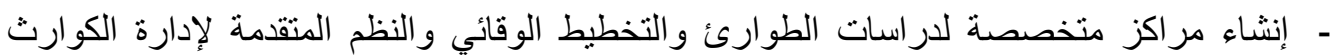

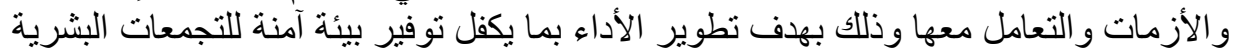

المراجع

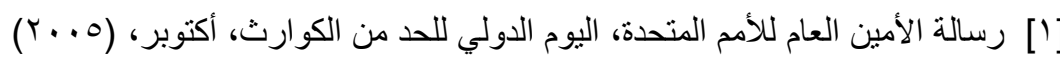

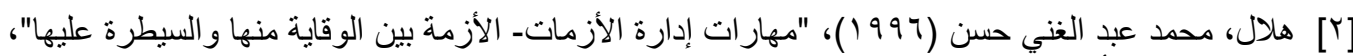

مركز تطوير الأداء وألتنمية، الطبعة الثانية

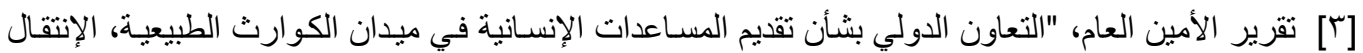

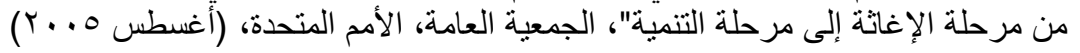

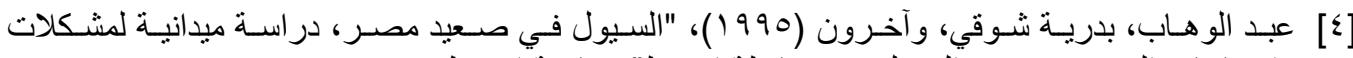

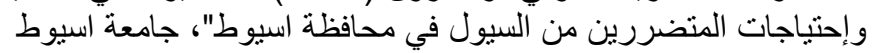

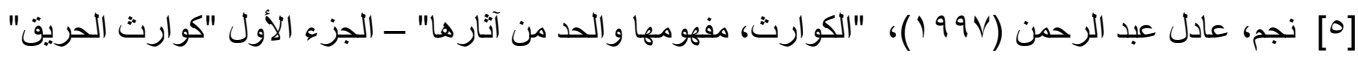

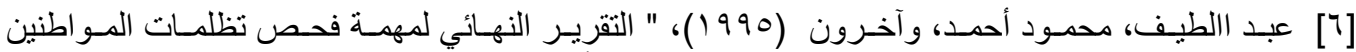

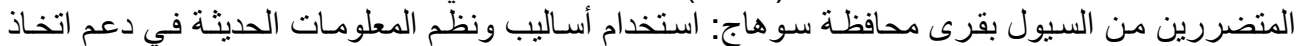

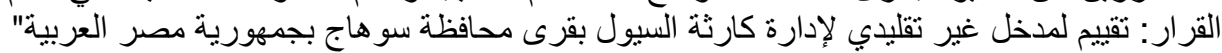

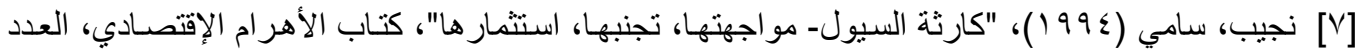

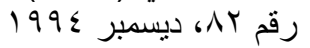

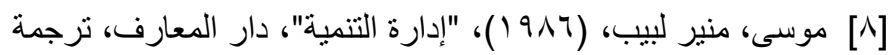

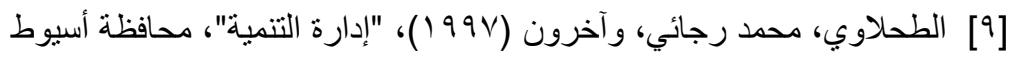

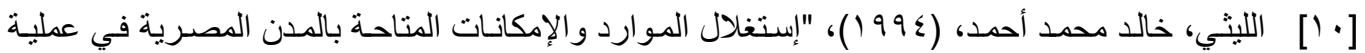

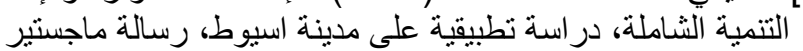

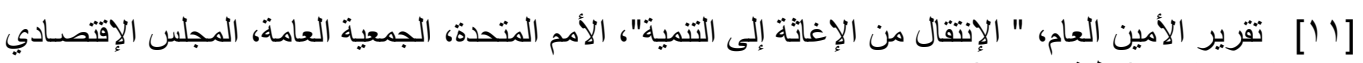

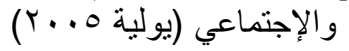

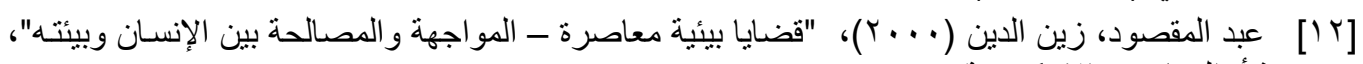

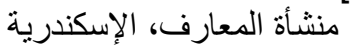

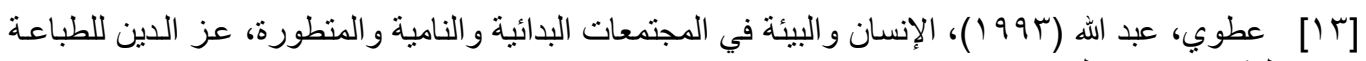

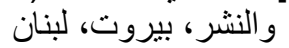

[ 1 ] الأشكال نم إعدادها بمعرفة الباحث بالإعتماد على المر اجع المستخدمة بالبحث

[15] El-Lithy, Khaled Mohamed. et al., (2003), "GIS-Based Regional Environmental Impacts Assessment Caused by Suburbanization Activities, Case Study in Muko River Basin Region", International Symposium on City Planning 2003, Planning, Regionalism, Coexistence, The City Planning Institute of Japan, Sapporo, Japan, pp. $121-130$ 